DOI: http://doi.org/10.4038/ss.v50i1.4721

\title{
Investigating Growth Performance of Sri Lanka
}

\author{
K. K. C. Sineth Kannangara ${ }^{1}$
}

\begin{abstract}
This study starts with an analysis of macroeconomic determinants on growth in the case of Sri Lanka, deploying the Autoregressive Distributed Lag (ARDL) approach using annual data from 1960 to 2018. Key findings of the study reveal that utilising the available policy spaces to create an investment conducive climate and to support exports is essential while revisiting the imports structure to understand the necessary potential improvements. Unexpectedly, total employment does not show a significant influence on the movement in real GDP, emphasising the challenging need for labour market reforms for enhancing workplace efficiency and proper labour management. Results show that the civil war arrested the revival of the economy and rejected the tourism-led growth bypothesis. Beyond the ARDL model, a Generalised Least Squares Panel Data model is employed, to analyse the impact of regional integration in the South Asian context on the growth of the Sri Lankan economy. Results of the Fixed Effects models prove that trade liberalisation drives the growth of panel economies and the existence of a non-linear positive relationship between export concentration and real per capita GDP growth. Accordingly, one could conclude that the growth of $S A A R C$ economies could flourish with trading amongst themselves, accompanied by free trade agreements.
\end{abstract}

Key Words: Panel Data Model, ARDL Model, Economic Growth, Sri Lanka

JEL classification: C33, C39, F14, O47

\footnotetext{
1 The author is currently serving as a Senior Economist of the Economic Research Department of the Central Bank of Sri Lanka. Email: sineth@cbsl.lk.

The author wishes to thank Associate Professor Dr Ishita Chatterjee of the University of Western Australia, for her guidance and support. The author also thanks Dr Chandranath Amarasekara, Director, Economic Research Department and others from the Central Bank of Sri Lanka for their valuable comments. A special thank goes to Dr Kapila Senanayake and Dr Kithsiri Ehelepola for the support given at the initiation of this study. Also, the author wishes to thank all friends who helped in many ways and anonymous reviewers, for their support. Finally, the author wishes to express gratitude to her beloved husband, Amal and daughter, Thasanya; if not for their understanding, this research would not have been possible. The views presented in the paper are those of the author and do not necessarily indicate the views of the Central Bank of Sri Lanka.
} 


\section{Introduction}

There is a consensus that economic growth increases the wealth of a country by alleviating poverty. According to pervasive literature which discusses different frameworks of economic development, growth of an economy could be coming from different pathways, such as physical capital accumulation (Solow, 1956, Swan, 1956, Kaldor, 1961), productivity improvements (Solow, 1962, Mankiw et al., 1992), improvements in human capital stock (Schultz, 1961, Barro, 1991, Becker et al., 1990), enhanced efficiency of financial markets (Levine et al., 1998) and improvements in external sector performance (Acemoglu, 2012, Grossman and Helpman, 1991). However, the pattern and speed of growth are inherently country specific.

Growth prospects of the Sri Lankan economy seemed promising and were well ahead of its Asian peers in the early post-independence era. At the time of independence in 1948, Sri Lanka was predominantly a small agrarian economy with Gross Domestic Product (GDP) of US dollars 953 million (current prices) and the share of agriculture was 62 per cent of GDP, while the services and industries sectors contributed 33 per cent and 5 per cent, respectively ${ }^{1}$. Since then, Sri Lanka pursued unique economic ideologies to reach a high and sustained development of the national economy. The government which was appointed in 1956, adopted a state-led inward looking approach along with the "welfare state model". However, the economy could not reach the anticipated performances through closed economic policies due to limitations of markets, lack of technical expertise, low productivity and increase in production costs, etc. (Menike, 2018). Later, growth prioritising inward looking policies were replaced by the outward looking policy package through economic liberalisation in 1977, that aimed at accelerating the economic growth and income generation by promoting exports and private sector investments, while opening avenues to reach external markets. Among other factors, this accelerated process of economic growth followed by privatisation policies introduced in the 1990s helped to transform the agriculture-based rural economy into a service-based modern economy, over time.

Remarkably, the Sri Lankan economy could not reap awaited outcomes of trade liberalisation mainly due to the rise of the so called "twin-political conflict" (Abeyratne et al., 2017; Abeyratne, 2004). ${ }^{2}$ The economy started losing the momentum gathered over trade liberalisation a few years after opening its economy. The inevitable result was that Sri Lanka expended a long time span of almost 56 post independent years to pass through the US dollars 1000 per capita GDP (PGDP) level. Mainly, with the outbreak of the separatist struggle in the

\footnotetext{
1 The services sector in the GDP constituted a share of 57.5 per cent by 2018 , followed by the industrial sector $(26.1$ per cent of GDP), leaving a lesser share to the agricultural sector (7.0 per cent of GDP), which had held a dominant share in the early phases of post-independence.

2 "Twin-political conflict" - the Tamil separatist war in the North and the Sinhalese youth uprising in the South
} 
early 1980s, successive governments were not able to enjoy the benefit of freedom to design long term macroeconomic policies to have sustained growth in the economy (Herath et al., 2014). Instead, they had to bear continued high military expenditure until the cessation of the separatist war with the Liberation Tigers of Tamil Eelam (LTTE) in 2009, which according to some researchers, caused a loss of both "blood and treasure" (Bandarage, 2008). After that, the economy started to gather its growth momentum, recording an average growth of 8.5 per cent during the 2010-2012 period. Explicitly, the economy upgraded with a numerous development in physical infrastructure during the post war era. Although it was not able to sustain such high germination for more than three years, the reduced risk and high return environment prevailed in the country during the conflict free period caused a high volume of foreign funds to flow into the economy while boosting new investments (Figure 1).

Noticeably, the country showed strong economic performances during some periods (Duma, 2007), despite overwhelming burdens stemming from the prolonged war. Concurrently, socio-economic development led by "welfare first" policies brought the country on par with developed and emerging market economies while paving the way for being an "aberration" in the sense of social development, (Lakshman, 1997). However, the economy is still highly vulnerable to the shocks emanating from economic imbalances; high twin debt and twin deficit levels, volatile exchange rate, frequent natural disasters, various policy and political swings all put together contribute to the sluggishness of the growth (Weerakoon et al., 2019; Dunham and Kelegama, 1997; Arunatilake et al., 2001). ${ }^{3}$ At the same time, many critics agree that the Sri Lankan economy has many idle avenues to improve, although it is growing significantly below potential. These developments in the spheres of polity and economy question the effectiveness of macroeconomic policies and are also worrisome for policymakers. In this backdrop, this study aims to analyse the effect of some selected leading macroeconomic variables, including export, import, capital formation, and earnings from tourism and employment, on the growth of the Sri Lankan economy. It collates annual data from several reliable sources constituting a sufficiently long period of 1960-2018 and uses the Autoregressive Distributed Lag (ARDL) approach in the analysis. It also uses a mix of controls depicting changes in macroeconomic, socio-political (such as civil conflict) and institutional (such as relaxing trade policies) segments of the economy, as crucial factors determining the economic growth of Sri Lanka. Besides, the use of the ARDL framework, which, to the best of the knowledge of the author, is a new approach for analysing economic growth in Sri Lanka.

\footnotetext{
${ }^{3}$ Twin debt: domestic debt and foreign debt

Twin deficit: current account deficit and budget deficit
} 


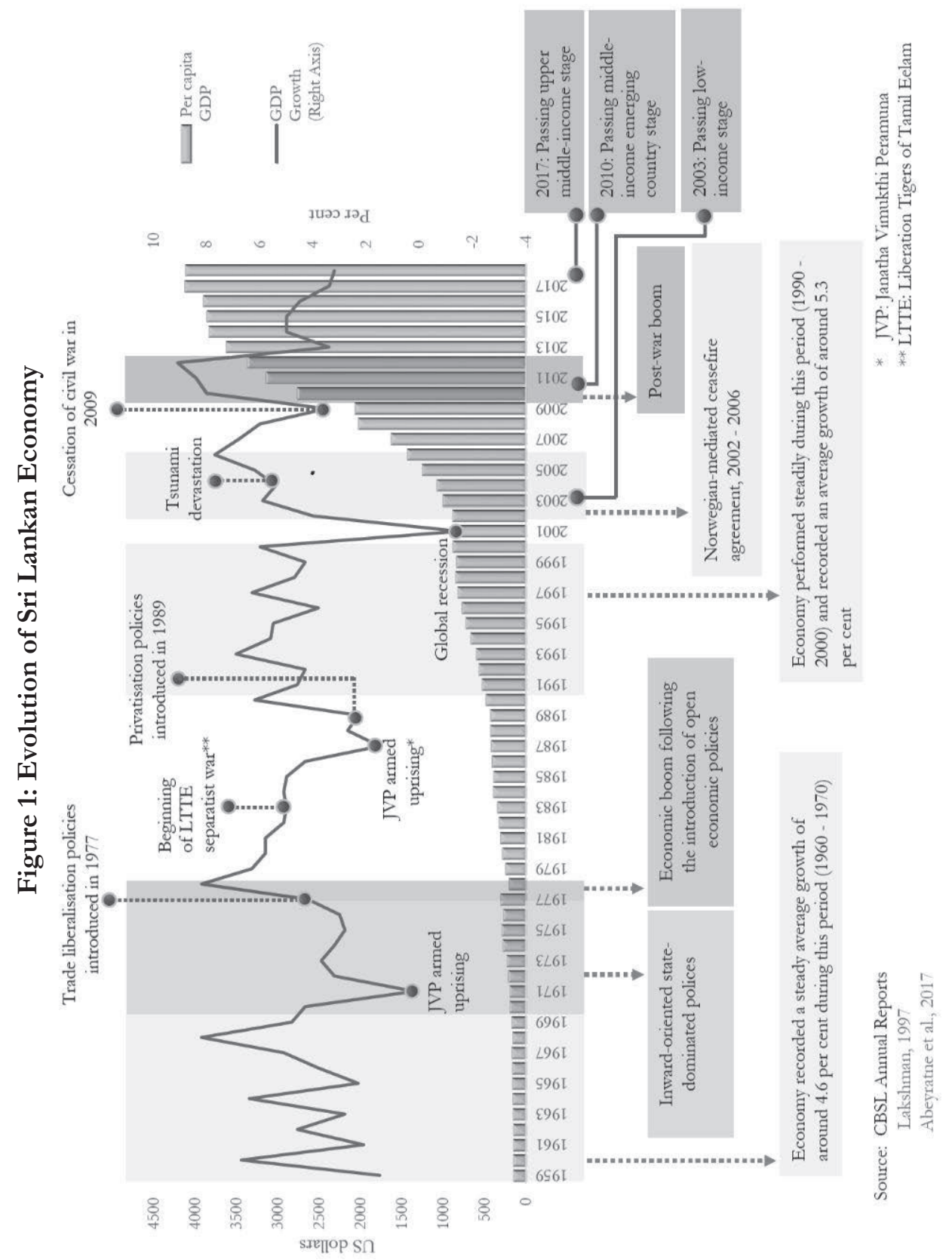


Further, regional integration within the proximate parts of the South Asian region, is dramatically increasing over different dimensions. It has been the topic of many available pieces of literature, which identifies regional integration as the next step of globalisation through trade liberalisation or open economic concepts (Mattli, 1999; Schiff and Winters, 2003). Therefore, this paper introduces a Generalised Least Square Panel Data model to study the regional growth of selected South Asian economies which belong to the South Asian Association for Regional Corporation (SAARC), and this distinguishes this study from others on the economic growth of Sri Lanka.

Both econometric analyses of this study, ARDL and panel data model, highlight the importance of trade liberalisation policies on growth. Although total employment as a proxy for the labour force has supported the growth of the Sri Lankan economy, this lacks explanatory power. Notably, growth is negatively related to tourism earnings in the long run, but there is a positive impact on growth in the short run. Also, socio-political instability caused by the civil conflict provides evidence about the detrimental effects on growth, as expected. The findings of the fixed effect model for selected South Asian economies agree with the key findings of the ARDL model while gross capital formation and FDI support the per capita GDP growth of panel economies. Also, the results make evident the existence of a non-linear positive relationship between export concentration, measured by the Hirschman Herfindahl index and real per capita GDP growth of panel economies. Accordingly, the author wishes to emphasise the vital importance of having a broader long term plan for the integrated development of each sector, labour market reforms, diversified export base and deepened trade relationships with the regional economies, and for the high and sustained development of the Sri Lankan economy.

The remainder of this paper is structured as follows. Section 2 depicts a historical overview of Sri Lanka's growth trajectory since independence, along with a literature survey. Section 3 discusses the theoretical framework. The empirical analysis, including data and methodology, and a description of variables and data, are presented in Section 4. Section 5 contains the results and Section 6 concludes with a discussion on the policy implications.

\section{Historical overview and literature survey}

\subsection{Pre-1977}

While gaining independence in 1948, Sri Lanka was recognised as a comparatively better off economy compared to many of its Asian peers, in terms of performance indicators such as per capita GDP. However, looking back a few decades later, many countries that started at a lower level, have surpassed Sri Lanka in respect of economic performance emphasising the need for reviewing the domestic economic policies (Table 1). 
By 1956, Sri Lanka was facing a demanding situation in managing foreign assets due to increase of unnecessary import bills along with the widened budget deficit, while the government had to survive with costly welfare facilities and soaring unemployment levels prevailing in the economy (Manike, 2018). Therefore, closed economic policies were proposed as appropriate and accordingly, "redistribution and poverty alleviation" were given the priority focus on the inward looking policies, while de-prioritising growth. Thus, various restrictions were imposed on imports, accompanied by extensive social welfare programmes, including food subsidies, retentive free education and free health care facilities, mainly aimed at improving the living conditions of the people (Abeyratne et al., 2017). As a result, the country performed well in

Table 1: Per capita gross domestic product (PGDP) of selected South Asian economies (as a percentage of US PGDP)

\begin{tabular}{lrrrr}
\hline \hline Country & \multicolumn{5}{c}{ PGDP } \\
\cline { 2 - 5 } & \multicolumn{1}{c}{1960} & \multicolumn{1}{c}{1970} & 1979 \\
\cline { 2 - 5 } Malaysia & 14.6 & 16.7 & 15.6 & 23.2 \\
Sri Lanka & 11.4 & $\mathbf{1 0 . 2}$ & $\mathbf{9 . 4}$ & $\mathbf{9 . 4}$ \\
Philippines & 10.3 & 11.4 & 11.7 & 13.3 \\
Thailand & 9.9 & 9.5 & 11.7 & 13.4 \\
Pakistan & 9.0 & 7.8 & 8.4 & 7.6 \\
South Korea & 7.6 & 8.2 & 11.8 & 24.8 \\
India & 7.1 & 7.5 & 6.5 & 5.7 \\
\hline
\end{tabular}

Source: Athukorala and Jayasooriya, 1994, Table 3.3

achieving a higher level of development as reflected by social development indices, on par with peer economies (Figure 2) 4 . However, implementation of such "welfare state" policies became a futile efforts due to high unemployment, low productivity, inadequate technical soundness, increased production costs along with high imported raw material costs, and limited access to external markets, so on (Manike, 2018). The market-oriented then government set their priorities for the continuation of the private sector dominated export policies inherited from the colonial administration, along with welfare programmes such as universal free education and health care facilities.

${ }^{4}$ IBRD: International Bank for Research and Development 
Figure 2: Socio-economic Development of Sri Lanka

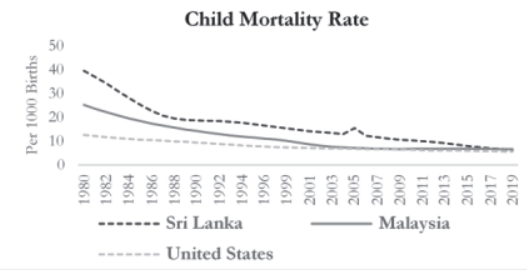

Source: Data Bank of IBRD

Human Development Index - 2018

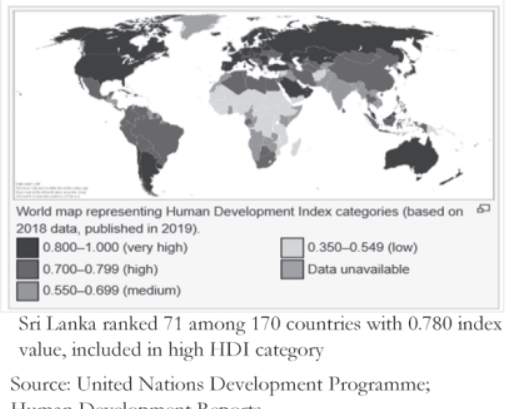

Human Development Reports

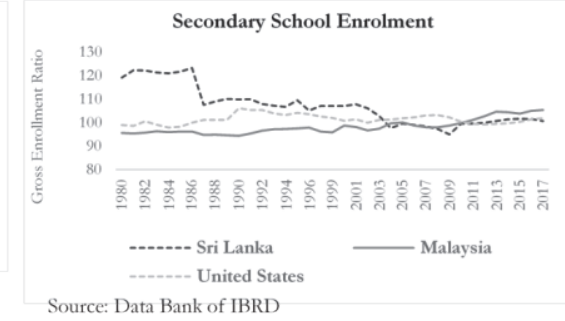

Governance Indicators - $2018 \quad$ Global Competitiveness Index - 2019

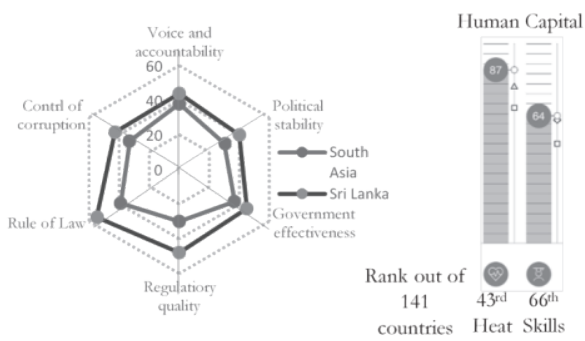

Source: Worldwide Governance Indicators Source: World Economic Forum

\subsection{Introduction of liberalisation policies in 1977}

The gradual introduction of liberalisation policies prioritising economic growth paved the way for domestic investors to reach external markets. Policy reforms introduced in 1977 included reductions and simplifications of tariffs and taxes, which facilitated further expansion of trade in the country. It further helped strengthen its trade relations with European and far eastern nations through its strategic positioning in the east-west maritime trade route that runs back to the pre-colonial era (Athukorala and Jayasooriya, 1994). Thereby, it exerted an unprecedented influence on the growth of exports and increasing domestic consumption (Herath et al., 2014). As a result, the country's growth seemed to be producing promising results, reflected by the higher growth of the economy recorded in the latter part of the 1970s. Notably, the trade reforms caused a significant takeoff in terms of export performance in Sri Lanka (Abeyratne et al., 2017). As a result, the export composition leaned towards more technology based manufacturing industries from labour intensive industries. In contrast, primary export goods shifted from tea to garments benefitting from quickly attracted foreign investments and supported by the comparative advantage of the country with abundant labour (Figure 3). Moreover, Sri Lanka's trade relations with other economies were strengthened 
Figure 3: Sri Lanka's Composition Exports (\% of total exports)
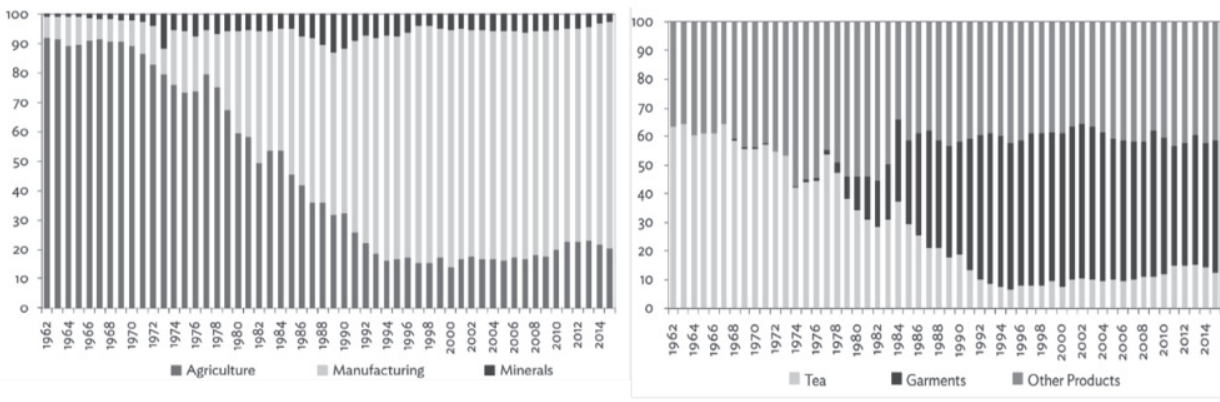

Source: Abeyratne et al., 2017, Figure 1.6 and 1.7

through several trade agreements such as APTA (1975), GSTP (1989), ISFTA (1998) PSFTA(2005), SAFTA (2004) and SLSFTA (2018) and Siriwardhana (2000) discusses that Sri Lanka gained from the bilateral trade relationships with South Asian Partners. ${ }^{5}$ There are many pieces of literature which discuss the positive externalities of trade openness through export promotion and import substitution including Lucas (1988), Barro (2001), Hausman et al. (2005), Giovanni and Levchenko (2009), whereas some other researchers discuss the detrimental effects of export and import with growth (Ulasan, 2012, Yanikkaya, 2003). However, we could expect that sectors with high expertise could grow faster. Workers in industries with higher comparative advantage, such as export oriented industries, could improve quickly due to enhanced proficiency in production, compared to import competing industries.

Unfortunately, Sri Lanka could not reap the anticipated benefits of the liberalisation policy package, due to several reasons. Firstly, social unrest, driven by the elevated level of unemployment and population growth arrested the revival of the economy. The educated unemployment went up during this period due to the low capacity of the labour market to provide white-collar jobs absorbing the increased level of educated youth produced by free education programmes (Dickens and Lang, 1991). Secondly, conflicts prevented successive governments from implementing long term development plans, instead they had to bear massive military financing (Athukorala and Jayasooriya, 2013). Thirdly, some literature attributes the underperformance of the liberalisation policy package to not accounting for the resulting adverse spillover effects on the multi-ethnic social fabric (Athukorala and

\footnotetext{
${ }^{5}$ SAFTA: South Asian Free Trade Agreement signed in 2004 with Afghanistan, Bangladesh, Bhutan, India, Maldives, Nepal, Pakistan and Sri Lanka

ISFTA: Free Trade Agreement signed between India and Sri Lanka in 1998

APTA: Asia Pacific Free Trade agreement includes, Bangladesh, China, India, South Korea, Sri Lanka and Laos signed in 1975

PSFTA: Pakistan - Sri Lanka Free Trade Agreement came in to being in 2005

GSTP: Agreement on Global System of Trade Preferences

SLSFTA: Sri Lanka -Singapore Free Trade Agreement signed in January 2018
} 
Jayasooriya, 2015). ${ }^{6}$ On the other hand, although the exports sector boomed significantly, the inadequate and less diversified export base is yet left as a critical challenge. Notably, the current account deficit widened as import expenditure outpaced export earnings due to the increase in oil imports and the import of non-productive goods such as personal vehicles while increasing the vulnerability of the economy to external shocks. ${ }^{7}$

Further, the early 25 years of the protracted separatist war (1983-2009) brought devastating effects in terms of the loss of human and physical resources which could otherwise have been invested in the building up of physical and social infrastructure (Bandarage, 2008). For example, the defense expenditure as a percentage of GDP is equivalent to 5.7 per cent in 1990 and escalated to 14 per cent of GDP in 2008, when the battle intensified. ${ }^{8}$ Other than the direct socio-economic impacts, it caused significant indirect effects on the economy, leaving hardship on policymakers and people (Thambiah, 1986). Lindgren (2004) discusses the direct and indirect economic costs of an armed conflict under three dimensions, namely external relations, the national economy and households. Direct expenditures on external relations include foreign debts, and indirect damages on external relations comprise of capital flight, discouragement of new foreign investments, emigration of the skilled workforce and reduction of tourist arrivals. Destroyed infrastructure and farmland, underutilisation of existing productive capacity, increased military expenditure and costs on refugee care are direct costs on the national economy. The economy lost many production opportunities as a result of the destruction situation, uncertainty and missed education opportunities for combatants. It increased investments for the short term and high returns, instead of the long term while imposing the indirect costs on the national economy. In the case of households, direct prices include death, injuries and illness, and indirectly they face food scarcity and inflation costs.

\footnotetext{
6 “The liberalisation reform package was implemented in a non-uniform and discriminatory manner; it favoured different regions, sectors, and particular segments of the population”(Athukorala and Jayasooriya, 2015).
}

7 Sri Lanka Development update, IBRD, 2019

8

\begin{tabular}{cr}
\multicolumn{2}{l}{ Defense expenditure as a share of GDP } \\
\hline \hline CBSL Annual Report 1996 & Per cent \\
\hline Salaries and Wages & 1.7 \\
Other expenditure & 4.0 \\
\hline CBSL Annual Report 2008 & Per cent \\
\hline Salaries and Wages & 2.0 \\
Other expenditure & 12.0 \\
\hline Source: Annual Reports - Central Bank of Sri Lanka (CBSL)
\end{tabular}




\subsection{Post conflict era: 2009 onwards}

Cessation of the LTTE separatist war in 2009 marks the beginning of a new era in the Sri Lankan economy. During the post war period, the tradeoff between military expenses and development, along with enhanced investor confidence instigated as a result of favourable state policies and the political stability (Bastian, 2013), resulted in an upsurge in the investments in physical infrastructure. ' Supportively, the findings of many researchers, including Hausmann (2005), Mankiw et al. (1992) and Bal et al. (2016) show that capital formation exerts a positive impact on economic growth. Thus, we could expect that such massive investments in capital formation should have supported the growth of the Sri Lankan economy.

The economy seemed to be bouncing back while unleashing its potential and reached US dollars 3000 per capita GDP level within the first two years of the end of the conflict, although the developments in the recent past have brought down such optimistic expectations. ${ }^{10}$ At the same time, some critics agree on the fact that the said infrastructure boom in Sri Lanka was a "debt-fueled" phenomenon and question its sustainability (Athukorala and Jayasooriya, 2015). However, expenditure based contribution to GDP growth shows that private consumption and investments represented by capital formation have contributed more towards the growth of the modern service economy, followed by exports (Figure 4). Over time, the economy has transformed in to a service based economy, gradually deviating from its traditional agriculture base. Given this situation, the economy is hopeful of regaining many missed opportunities, especially in the tourism industry.

9 Sri Lanka performed as the most improved country in the South Asian region. In terms of infrastructure development, it records a value of 69.2 , being the best country in the region, followed by India.

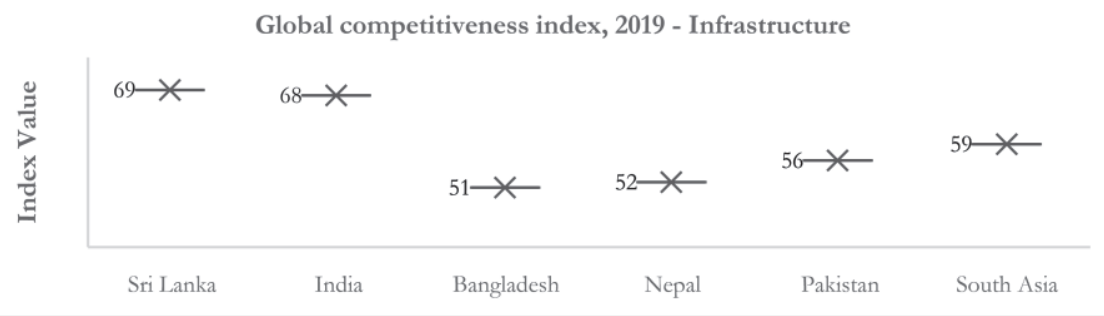

Source: World economic forum, 2019

10 The International Monetary Fund (IMF) announced Sri Lanka as a middle-income emerging country in 2010 and it was graduated as an upper-middle-income country in 2018 with a GDP per capita of US dollars 4,102 (International Bank for Research and Development). 


\section{Figure 4}
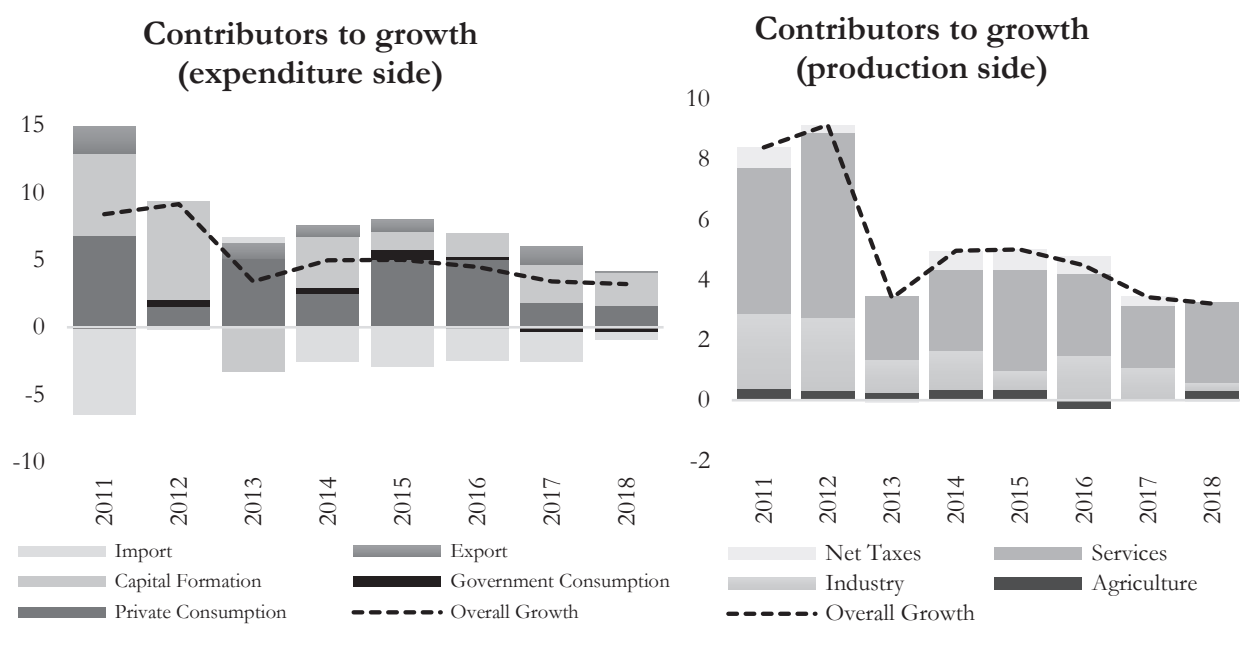

Source: Department of Census and Statistics, Sri Lanka

Tourism is been considered as one of the most promising sectors in the conflict-free environment. Successive governments have instigated diversified frontline policies targeting the development of the tourism industry and, especially the improved level of mobility across the country due to the safe and peaceful environment in the post war era which provided the much needed impetus to boost investments in tourism (Fernando, 2016). ${ }^{11}$ For example, several massive tourism projects, naming few, the Kuchchaweli Beach Resort project and the Dedduwa Development Project were launched after 2010, and the Dedduwa Development Project is known as the biggest tourism project thus far initiated in Sri Lanka covering 1800 hectares. Such projects capitalise the inherited potential as well as left opportunities in the country to grow as one of the best tourist destinations in the world while supporting inclusive development (Fernando, 2017). Particularly the country as a UNESCO world heritage site with its renowned rich natural landscape, diverse ecosystems, and glorious cultural heritage, is enriched with a high potential to improve the tourism industry as the prime foreign exchange earner of the country (Buultjens et al., 2016). ${ }^{12}$ Further, a case study conducted by Chandralal (2010) shows that tourism growth in Sri Lanka could improve the property values of Sri Lanka, which in turn could support the growth of the economy. However, recent updates display a

11

i. The ten-year master plan for tourism development, 1966 to 1977

ii. The "five hubs plus tourism" strategy, 2010

iii. Tourism Development Strategy, 2011-2016

iv. Sri Lanka Tourism Strategic Plan, 2017 - 2020

12 UNESCO - The United Nations Educational, Scientific and Cultural Organisation 
sharp decline in tourist arrivals in the aftermath of the Easter Sunday incident, which indicates the vulnerability of the tourism sector on political stability and social security, while agreeing with the fact that peace is not only the sufficient factor in developing the tourism industry (Lokuhetti et al., 2013).

A parallel transformation could be observed in the labour market, along with the structural changes which underwent in the economy. Accordingly, the services sector absorbed a significantly higher share of employees while leaving a lesser share in the agriculture sector, which was comparably high during the time of independence. Yet, the provincial distribution of employments shows that a higher number of employees in states are engaging primarily in agriculture related jobs. In contrast, services-related white collar jobs have become popular among the employees in urban areas (Abeyratne et al., 2017) (Figure 5). Mainly, the universal free education policies have resulted in generating an educated labour force in the country becoming 92 per cent literal by 2018 . However, enhancing the quality of labour appropriately empowering persons with necessary skills is required to improve the competitiveness of our exports in the global markets as well as to avoid the structural barriers along the path of graduating to the developed stage (Ganatlilaka et al., 2010).

On the other hand, government led policies, those aimed at forming a government sector engineered economy, caused a drastic increase in the public sector employment in Sri Lanka. Many researchers discuss the low efficiency of the public sector which not only nurtured economic inefficiency (Athukorala, 1994) but also transformed the wealth towards the public sector and deprived the private sector opportunities through rent-seeking (Gelb et al., 1991). Further, female labour force participation and employability in Sri Lanka need improvements considering different avenues such as social and cultural factors, high unemployment among well educated women and familial expectations as discussed by Malhotra and DeGraff (1997).

\subsection{Regional integration of SAARC economies - 1985}

The South Asian Association for Regional Cooperation (SAARC) came into being in 1985, with a broader view of accelerating economic integration in South Asian economies through mutual collaboration and assistance (Rahman et al., 2012). Some scholars find South Asia to be the least integrated region in the world when integration is measured in terms of trade in goods, capital and ideas (Ahmed and Ghani, 2007). Some other literature shows that the developments in terms of institutional and economic cooperation of SAARC countries are very limited (Rajapakse and Arunatilake, 1997; Iqbal, 2006). It is identified that FDI and terms of trade are the drivers of deepening and widening reciprocal regional growth (Zaman et al., 2011, Ali, 2014). Although India, the largest economy in the region, leads the regional growth Ali (2014) emphasises that the lack of resources in the region impedes economic integration. 
Further, Hesse (2009) studies export diversification and economic growth using a panel of 99 countries and highlights the importance of export diversification using the Hirschman Herfindahl $(\mathrm{HH})$ index. $^{13}$

Figure 5: Employment in major sectors in 2018

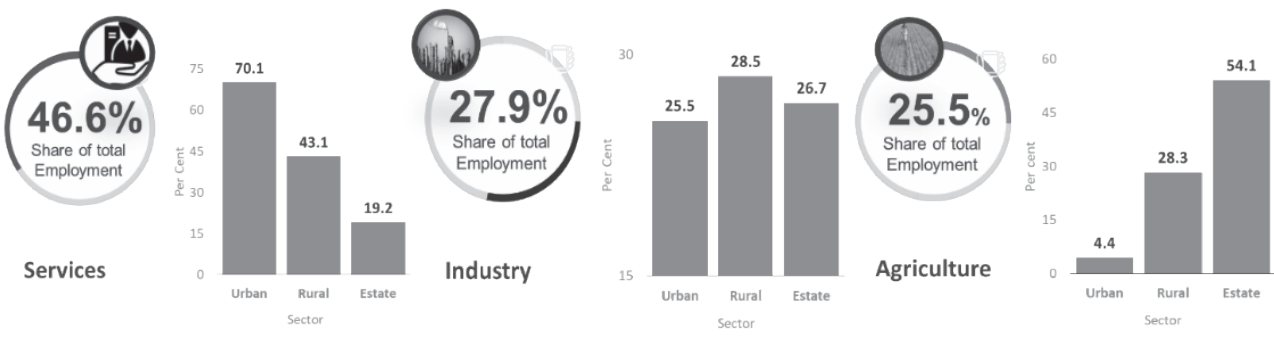

Source: Department of Census and Statistics, Sri Lanka

Figure 6 shows the behaviour of export concentration of selected South Asian economies, measured by the HH index and GDP per capita. Accordingly, Sri Lanka, India and Bangladesh show a clear inverse relationship between per capita GDP and the HH index, whereas Pakistan shows mixed performance. However, Nepal, being a country with more than 50 per cent trade relations only with India, does not show the expected pattern between export concentration and per capita GDP. Further, Ahmed and Ghani (2007) find that reduced trade barriers and trade reforms in the economies of the SAARC region need to be more competitive, stable, and adaptable. Further, FDI is an influential tool for accelerating economic growth of developing countries, as it creates channels to enhance the growth process of the beneficiary economy as well as the host economy (Barrel and Pain, 1997), not only through transferring technology but also by sharing technical know-how, creating employment, and improving the quality of human capital via exposure and skills development (Alfaro, 2003, Alfaro and Chauvin, 2016). Further, in the Sri Lankan context, Rajapakse and Arunatilake (1997) uses the gravity model to examine the impact of intra-SAARC trade and show that there is considerable

\footnotetext{
13 "Hirschman Herfindahl index is a measure of the dispersion of trade value across an exporter's partners. A country with trade (export or import) that is concentrated in a very few markets will have an index value close to 1 . Similarly, a country with a perfectly diversified trade portfolio will have an index close to zero", IBRD Interpretation. Link to manual: http://wits.worldbank.org/WITS/doc/TradeOutcomes-UserManual.pdf.
} 
Figure 6: Dispersion of Trade and Per Capita GDP of Selected South Asian Economies

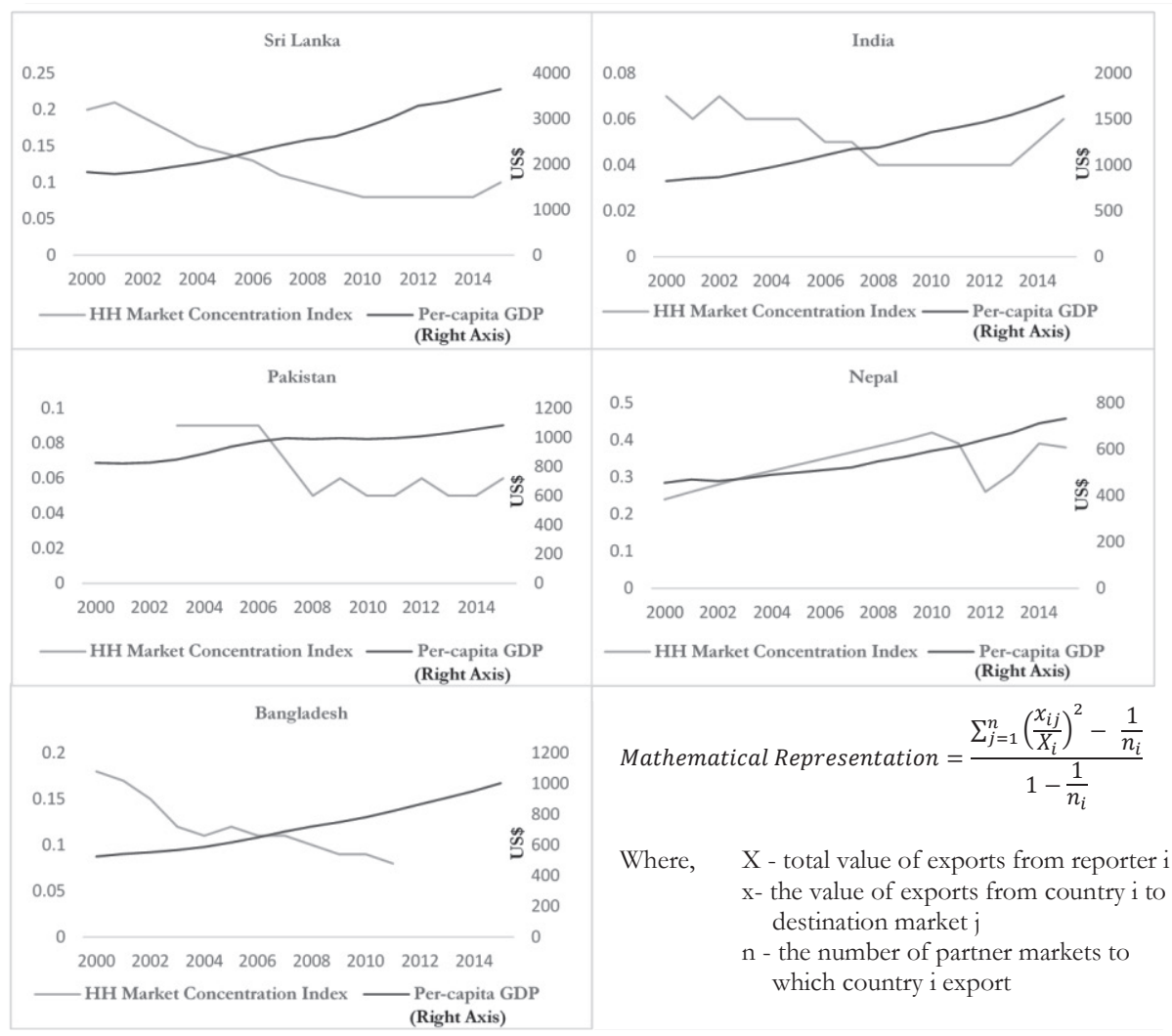

Source: TCdata360, International Bank for Research and Development (IBRD)

potential for further enhancing bilateral trade relations of Sri Lanka with other SAARC economies. Moreover, as shown in Figure 7, although inter regional trade share shows a highly volatile pattern, Sri Lanka's current trade relations with other countries in the SAARC region show an increasing tendency, in terms of both volume and share of total trade. 
Figure 7: Sri Lanka's Trade with SAARC Countries

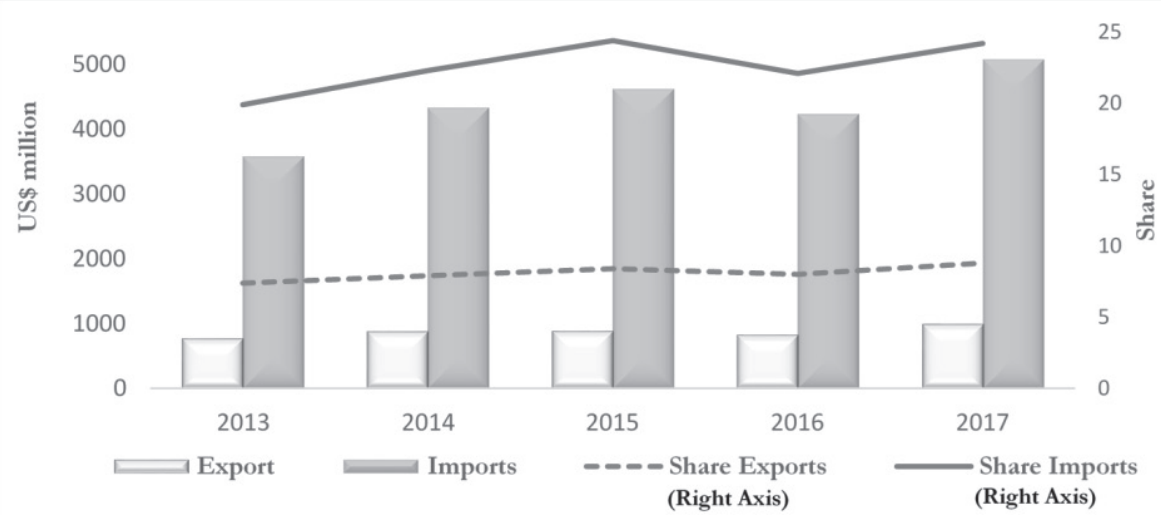

Source: CBSL annual report 2017, statistical appendix, Table 84 \& 85

\subsection{Other country studies}

Barro (1991) examined the growth rate of real per capita GDP in a cross-section of 98 countries for the period 1960-1985 and found that a higher share of physical investment to GDP exists in countries with higher human capital. Barro (1996) further expanded Barro (1991) using a panel of 100 countries and showed that improvements in terms of trade boost growth. Barro (2001) established a positive relationship of international openness (ratio of exports plus imports to GDP) and terms of trade (the ratio of export prices to import prices) with the growth of GDP. Levine and Renelt (1992) studying 119 countries manifest the fact that average GDP growth rate is positive and robust to the share of trade in GDP and investment. Further, Hausman et al. (2005) study growth accelerations of 110 countries and shows that the terms of trade shock and financial liberalisation are statistically significant parameters. The study also makes it evident that social chaos, such as armed external or internal conflicts do not bring a significant effect on the likelihood of growth accelerations. Research even convinces FDI to be an obvious determinant of growth. Borensztein et al. (1998) use a panel of 69 developing countries for a twenty year period, and results show that FDI contributes more to the growth compared to domestic investment. On the contrary, Carkovic and Levine (2002) find in an analysis of 72 countries over the period 1960-1995 that there is no robust significant relationship of FDI on growth. Further, among other researchers, Alfaro (2003), Karimi and Yusop (2009), and Zhang (2001) using cross-country data suggest that there is an ambiguous effect of FDI on growth. 


\section{Theoretical Framework}

\subsection{A Brief introduction to growth theories}

Solow Growth Model: Solow (1956) discusses the long run relationship between real income with the growth of capital stock, growth of labour force and exogenous technological advances.

Consider the aggregate production function,

$$
Y_{t}=A_{t} H_{t}^{\alpha} K_{t}^{\beta}
$$

Where $Y_{t}$ is aggregate output, $A_{t}$ denotes total factor productivity, $K_{t}$ represents the physical capital stock, $H_{t}$ is the aggregate human capital stock, and $\propto$ is the elasticity of final output to the human capital stock, which could be represented by, $\propto=\frac{\partial Y_{t}}{\partial H_{t}} \cdot \frac{H_{t}}{Y_{t}}$ and $\beta$ is the elasticity of final output to the physical capital stock, which could be represented by, $\beta=\frac{\partial Y_{t}}{\partial K_{t}} \frac{K_{t}}{Y_{t}}$ and $k_{t}=\frac{K_{t}}{H_{t}}$. The introduction of depreciation to the model shows that the steadystate level of per capita capital stock does not change, as the amount of investments equals the amount of depreciation, $\delta \kappa$. However, with the introduction of new technologies and new investments, capital is accumulated over time, and steady-state potential will grow with large capital stock and a high level of output. Change in capital stock could be represented by $\Delta \kappa$, where $\Delta k=k_{t}-k_{t-1}$. Thus, the investment, $I$ in the period $\mathrm{t}$ is $\left(\delta k_{t-1}+\Delta k\right)$. Accordingly, $\Delta k=I_{t}-\delta k_{t}$, and at the steady state, investment equals the savings. Thus, $\Delta \kappa=s f(\kappa)-\delta \kappa_{t}$, where $s$ is the $\Delta \kappa=s f(\kappa)-\delta \kappa_{t}$, where $s$ is the marginal propensity to save. If we consider the technological change $(\mathrm{g})$, and population growth $(n)$, capital accumulation is represented by, $\Delta k=s f(k)-(\delta+n+g) k_{t}$, and graphically shown in Figure $8 .{ }^{14}$

$14 \delta k_{t}:$ Depreciation of capital

$n k_{t}$ : Capital required for new workers

$g k_{t}$ : Capital required to cover enhanced efficiency of workers 


\section{Figure 8: Solow Growth Model}

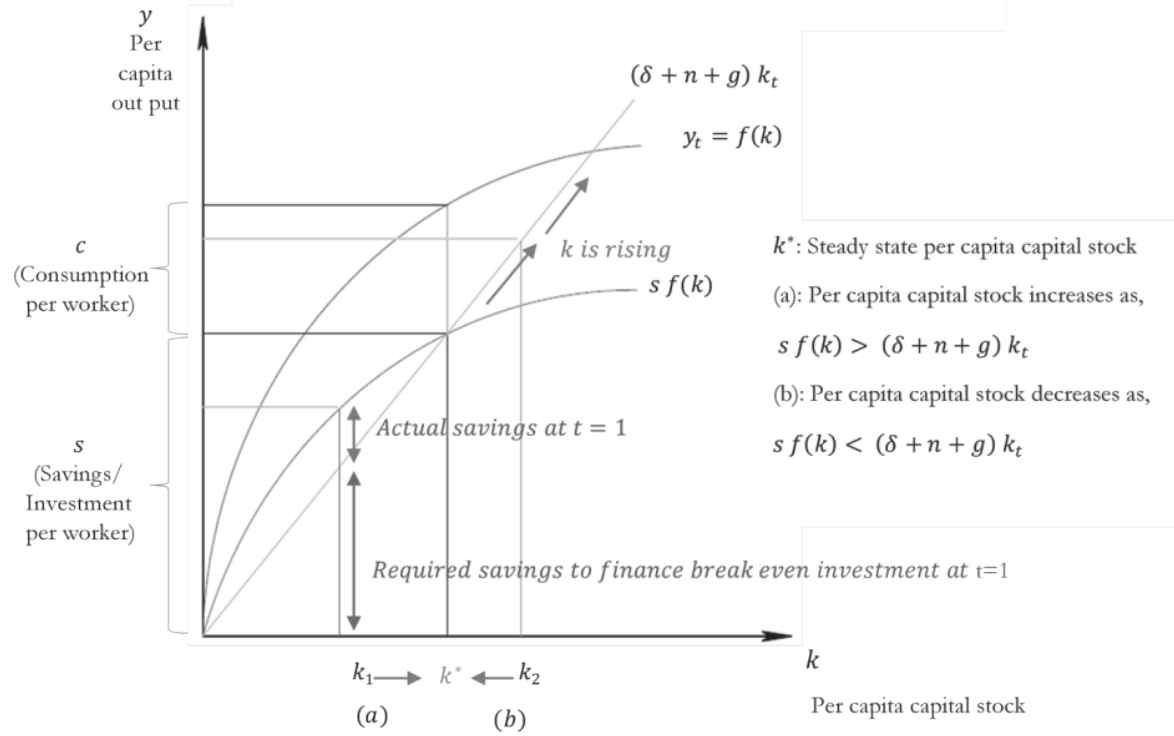

\subsection{An Introduction to Econometric Analysis}

Selecting the model that suits a given data set is crucial in a time series analysis. If one does not select the appropriate methodology or use a wrong specification, the model will generate unrealistic estimates. Further, any econometric regression should at least capture interactions and integrations of variables over time as well as distinguish the long run (elasticity) and short run (slope) behaviour of the data. A simple illustration of the basic model selection criteria is shown in Figure 9.

\subsubsection{ARDL model:}

The ARDL model also referred to as the bounds cointegration technique, is formed using two main components: the autoregressive element for which the current value of the dependent variable is considered to be a function of past values itself, and the element of distributed lag in which current and past values of explanatory variables are considered to be a function of the dependent variable. ARDL is a standard least squares regression method which is widely used in the regression analysis due to many econometric advantages over other cointegration techniques such as the residual approach of Engle and Granger (1987) or the maximum likelihood approach introduced by Johansen and Julius (1990). Pesaran et al. (2001) show that the ARDL approach can be applied irrespective of the fact that we use $\left(\mathrm{I}_{0}\right),\left(\mathrm{I}_{1}\right)$ or a mix of $\left(\mathrm{I}_{0}\right)$ and $\left(\mathrm{I}_{1}\right)$ variables. Further, after estimating the order of the ARDL, OLS estimation is prescribed for the regression, and the researcher could be free from identifying the order of 
the underlying data, compared to general error correction estimation. Furthermore, this procedure can be used regardless of the sample size, very large or small, ensuring stable and consistent results in the long run. As explained by Enders (2004) and Wooldridge (2008), the estimated model best fits the actual data-generating process, only if the residuals satisfy the diagnostic tests. Accordingly, the presence of cointegration vectors for the existence of a long run relationship, satisfying the Bounds Test (F-test), and the absence of serial correlation and heteroscedasticity, confirm the fitness of the ARDL model. Akaike Information Criterion (AIC) should be satisfied for the model to fit statistically. Further, the model should be unbiased, i.e. normally distributed and stable, tested by recursive residual test for structural stability (CUSUM recursive estimates).

The general ARDL Model of order $\mathrm{p}$ and $\mathrm{q}, \operatorname{ARDL}(\mathrm{p}, \mathrm{q})$ takes the following regression form,

$$
A R D L_{p, q}=Y_{t}=\mu+\sum_{k=1}^{p} A_{k} Y_{t-k}+\sum_{j=0}^{q} B_{j} X_{t-j}+\varepsilon_{t}
$$

Accordingly, for an ARDL model, $Y_{t}=A_{0}+A_{1} Y_{t-1}+A_{2} Y_{t-2}+\cdots+A_{\mathrm{p}} Y_{t-p}+B_{0} X_{t}+$ $B_{1} X_{t-1}+\cdots+B_{q} X_{t-q}+\varepsilon_{t}$; the short run effect (Static Effect) is $\frac{\partial Y_{t}}{\partial X_{t}}=B_{0}$ and the Long run Effect (Dynamic Effect) is, $\frac{\partial Y_{T}}{\partial X_{t}}=\frac{B_{0}+B_{1}+B_{2} \ldots .+B_{q}}{1-A_{1}-A_{2} \ldots \ldots . . A_{p}}$ and the Error Correction Model of the ARDL takes the form, $\Delta Y_{t}=B_{0} \Delta X_{t}-\pi E C T_{t-1}+U_{t} \cdot{ }^{15}$

Figure 9: Model Selection Criteria

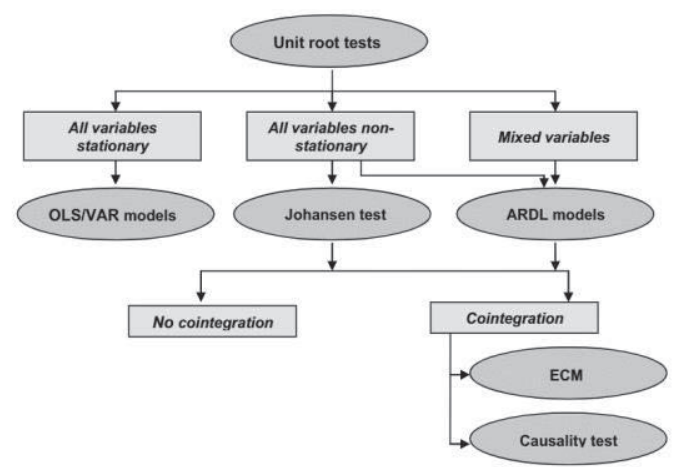

Source: Shrestha and Bhatta (2018); Fig. 6

\footnotetext{
15 Appendix A.1 provides a simple proof of static and dynamic effect coefficients of an ARDL Model.
} 
3.2.1.1 Bounds Test: To overcome the problems of non-stationarity cointegration techniques are used in econometric analyses as a better way of distinguishing the existence of steady state equilibrium among variables. Further, if the variables in a regression are not cointegrating, the results are considered to be meaningless. Therefore, the Bounds test is used to determine the long-run relationship of a series (Pesaran et al., 2001), and the F-statistic value of the Bounds Test determines the existence of cointegration among variables. The null hypothesis of the test assumes, there is no co-integration among variables. When the F-value produces less than the lower critical bound values, we conclude that there is no co-integration, whereas, when F-statistic is higher than the upper critical bound value, the variables are said to be co-integrated. However, when F-statistics falls between the upper and lower bound values, the Bounds test produces inconclusive results.

3.2.1.2 AIC Criteria: Given a collection of models for a data set, the AIC criterion developed by Akaike (1981) is used to measure relatively how well a model fits statistically. Adding coefficients to a model lowers the sum of squares of residuals estimated in the model while reducing the degrees of freedom. Therefore, the optimal lag length of an ARDL model could be determined in terms of the results of AIC criterion. In E-views, the following formula is used to calculate the fitness of the model using AIC value.

$$
A I C=-2 \ln \left(\frac{L}{T}\right)+2\left(\frac{n}{T}\right)
$$

Where,

$$
\begin{aligned}
& \mathrm{n}=\text { Number of parameters estimated } \\
& \mathrm{T}=\text { Number of usable observations } \\
& \mathrm{L}=\text { Maximised value of the log of the likelihood function. }
\end{aligned}
$$

\subsubsection{Panel data regression:}

Regression which disregards the space and time dimensions of the pooled data and estimates the form $y_{i t}=\propto+x_{i t} \beta+u_{i t}$, is a usual Ordinary Least Square (OLS) Regression, where, $u_{i t}$ is the disturbance term and $i=1,2 . ., I$ and $t=1,2, . ., T$ (Gujarati, 2004). If it is required to take special time-invariant individual features or unobserved heterogeneity of each cross sectional unit, we should let the intercept $\left(\mu_{i}\right.$; where $\left.u_{i t}=\mu_{i}+v_{i t}\right)$ change for each unit. Then the model is known as a Fixed Effects (FE) Regression Model or Least-Squares Dummy Variable (LSDV) Regression Model. Same as above, the model could be controlled for time effects such as technological changes by introducing time dummies, and the disturbance term could be written as $u_{i t}=\mu_{i}+\lambda_{t}+v_{i t}$ (Gujarati, 2004). However, the FE Model suffers from an enormous loss of a degree of freedom, due to the introduction of a large number of fixed coefficients in the model. To overcome this problem, we can use the Random Effects 
Regression (RE) Model or Error Components Model (ECM), which assumes $\mu_{i}$ as random (Baltagi, 2008) and is not correlated with the error term. Hence, if we do not include all relevant predictor variables in the analysis, the RE model can suffer from omitted variable bias. However, this model is most advantageous if it is required to include time variant characteristics. Accordingly, we can write the basic model equations as follows:

$$
\begin{array}{ll}
\text { Panel OLS: } & y_{i t}=\alpha+x_{i t} \beta+u_{i t} \\
\text { FEM: } & y_{i t}=\alpha+x_{i t} \beta+u_{i t} \\
& \text { Where; } u_{i t}=\mu_{i}+v_{i t} ; \quad \text { for cross-section fixed effects } \\
& u_{i t}=\mu_{i}+\lambda_{t}+v_{i t} \text {; for cross-section and period fixed effects } \\
\text { REM: } \quad y_{i t}=\alpha+x_{i t} \beta_{j}+u_{i t} & \\
& \text { Where; } u_{i t}=\mu_{i t}+v_{i t}
\end{array}
$$

In a panel data analysis, the Hausman test is the econometric device which decides between the fixed effects (FE) model and the random-effects (RE) model (Greene, 2003), where the null hypothesis tests the preferred model being a random-effects model. Also, the Redundant Fixed Effects - Likelihood Ratio allows to check the significance of the cross-section effects, period effects and joint significance of effects in the restricted specification, using sums-ofsquares, i.e. Chi-square test.

\section{Data and methodology}

\subsection{The ARDL model for the growth of Sri Lanka}

The ARDL model used to analyse the growth relationship of the Sri Lankan economy includes six independent variables: gross capital formation (CAPF), exports (EX), imports (IM), employment (EMP), tourist earnings (TE) and dummy variables, while real-GDP is being the dependent variable. Two dummy variables introduced in the model representing civil conflict (DWAR), and trade liberalisation (DTLIB) and, annual data from 1960 to 2018 are used in the analysis. The use of the ARDL approach for analysis of the growth of Sri Lanka is mainly justifiable since we have a mix of $I_{0}$ and $I_{1}$ variables and a sample of 59 observations. Further, many researchers, for example, Verma (2007), Gounder (2001) and Brida at al. (2016), have used the ARDL approach to determine growth relationships. 
The ARDL model takes the following form:

$$
\begin{aligned}
(\text { Real_GDP })_{a, b, c, d, e, f} & \mu+\sum_{k=1}^{a} \propto_{k} \text { Real_GDP }_{t-k}+\sum_{j=0}^{b} \beta_{j} C A P F_{t-j} \\
& =\mu \\
& +\sum_{l=0}^{c} \beta_{l} E X_{t-l}+\sum_{m=0}^{d} \beta_{m} I M_{t-m}+\sum_{n=0}^{e} \beta_{n} E M P_{t-n}+\sum_{p=0}^{f} \beta_{p} T E_{t-p} \\
& +D T L I B+D W A R+\varepsilon_{t}
\end{aligned}
$$

Table 3 provides descriptive statistics and ADF test results and refer Table 4 for the details of the variables.

\subsubsection{Checking the fitness of models ${ }^{16}$}

Bounds test: The bounds test results show that the null hypothesis is rejected at $1 \%$ level I(1) Bound, $4.15<$ F-statistic, 6.57. Accordingly, it is determined that there exists a long-run relationship among the variables at $1 \%$ level.

Table 2: Fitness of Models

\begin{tabular}{ccccr}
\hline \hline Test Statistic & Value & Significance & $\mathrm{I}(0)$ & $\mathrm{I}(1)$ \\
\hline \multirow{2}{*}{ F-statistic } & $\mathbf{6 . 5 7 2 3 1 3}$ & $10 \%$ & 2.08 & 3 \\
$\mathrm{k}$ & 5 & $5 \%$ & 2.39 & 3.38 \\
& \multirow{2}{*}{5} & $2.5 \%$ & 2.7 & 3.73 \\
& & $\mathbf{1 \%}$ & $\mathbf{3 . 0 6}$ & $\mathbf{4 . 1 5}$
\end{tabular}

AIC criteria: The result of the AIC criteria given below shows that the sequence 2,6,4,2,4,6 is the proper lag length for real GDP, capital formation, exports, imports, employment and tourists earnings, respectively.

\footnotetext{
${ }^{16}$ Results of the Model 8 are used as the reference for this discussion.
} 
Figure 10: Akaike Information Criteria (top 20 models)

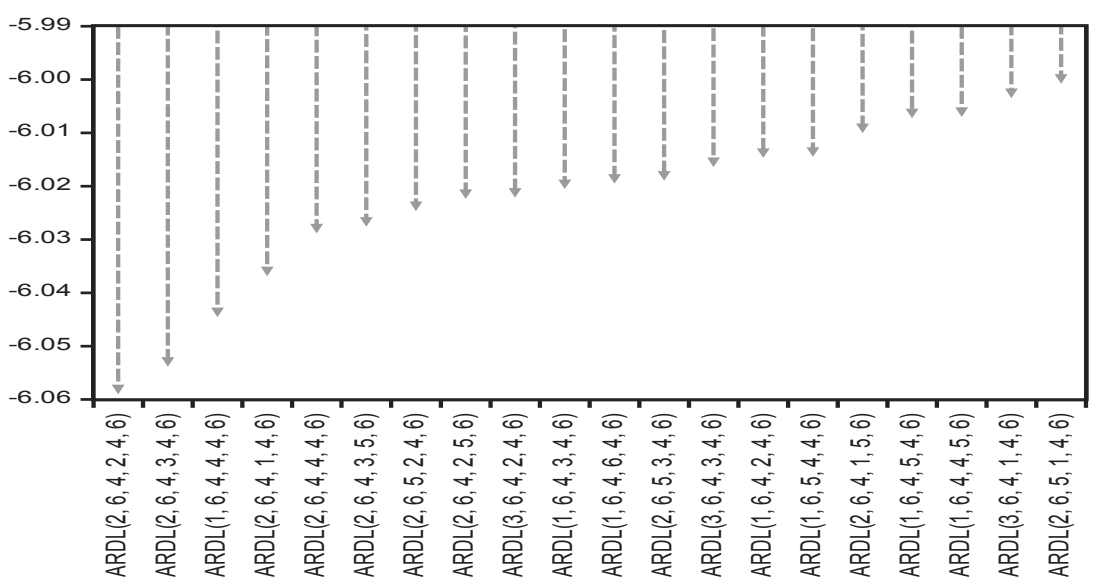

Stability Diagnostics - Recursive estimates of CUSUM Test: The result of the CUSUM test shows that the model is stable at 5 per cent significance level.

Figure 11: Recursive estimates of CUSUM Test

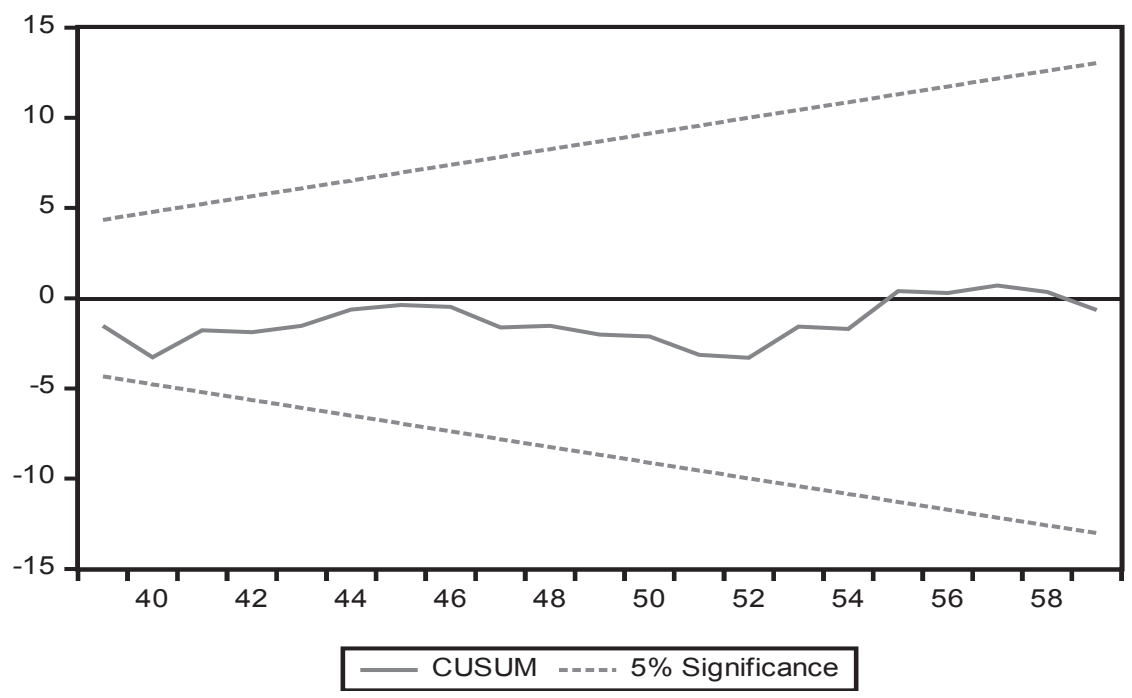




\subsection{Panel data model for the growth of South Asian economies}

The panel data model used to analyse the integrated regional growth of selected five SAARC economies includes several regressor variables: gross capital formation (CAPF), imports (IM), exports (EX), foreign direct investment (FDI), HH index, time trend and a dummy variable representing trade liberalisation period of each country (DTLIB), with annual frequency for the period from 1975 to 2017 at constant 2010 prices. ${ }^{17}$ Accordingly, there are 210 observations included in the panel, and per capita GDP (PGDP) is used as the predicted variable, paying due consideration to the relative comparison of the statistics of different countries. ${ }^{18}$ Accordingly, the test equation takes the following form:

$$
\begin{gathered}
d \log (P G D P)_{i t}=\propto+d \log (C A P F)_{i t} \beta_{1}+d \log (I M)_{i t} \beta_{2}+d \log (E X)_{i t} \beta_{3}+ \\
d \log (F D I)_{i t} \beta_{4}+(H H)_{i t} \beta_{5}+(H H)_{i t}^{2} \beta_{6}+(D T L I B)_{i t} \beta_{7}+t \beta_{8}+u_{i t} \\
\text { where } u_{i t}=\mu_{i}+\lambda_{t}+v_{i t}
\end{gathered}
$$

The test results justify that the use of the two-way FE model fits the selected sample of data.

\section{Empirical analysis and results}

\subsection{ARDL model}

Table 5 summarises long run results of the ARDL analysis and short run results (Model 8) are given in Table 6. In general, long run impacts are higher compared to the short run impact of all variables used in the analysis. Results make it evident that gross capital formation exerts a robust positive impact on the real GDP growth of Sri Lanka, as expected and as manifest in many works of literature including Hausmann et al. (2005), Mankiw et al. (1992) and Bal et al. (2016). The results are statistically significantly different from zero at one per cent level. When the capital formation is increased by one per cent, real GDP will increase by 0.52 per cent in the long run. Increase in government spending for raising fixed capital could significantly

17 All variables are as shares of GDP and in log difference form. Trade openness is defined as the sum of exports and imports as a share of GDP. A complete set of data of HH index is only available for 2000 - 2015 for selected five countries. Thus, models 4 and 5 include 80 observations in each model.

Out of the eight countries in SAARC, India, Pakistan, Sri Lanka, Bangladesh, and Nepal are the only countries included in the panel data model due to data constraints, which could otherwise lead to having a high number of null parameters in the regression matrix.

18 Source: DataBank of the World Bank and TCdata360 of IBRD 
boost economic activities over the near term mainly due to job creation, increase in consumption and developments in demand and supply conditions, as is also evident by the short run results of this study. Generally, an investment in the physical capital is associated with timing lags in terms of both implementation and value addition. Other than its direct impacts capital formation creates indirect impacts on growth through improved production capacity and technological improvements (Fisher, 1993).

Employment has excreted a detrimental effect on real GDP growth in the short run and becomes positive in the long run, though the results are not statistically significant. The result is in line with the discussions of Athukorala and Jayasooriya (1994) and Gelb et al. (1991) which direct us to surmise that employment in Sri Lanka is less utilised and if not, it would have boosted the growth of the economy than realised.

Table 3: Descriptive statistics and ADF test results

\begin{tabular}{lrrrrrr}
\hline \hline & $\begin{array}{c}\text { Log } \\
\text { (Real_GDP) }\end{array}$ & $\begin{array}{c}\text { Log } \\
\text { (Capital } \\
\text { Formation) }\end{array}$ & $\begin{array}{c}\text { Log } \\
\text { (Exports) }\end{array}$ & $\begin{array}{c}\text { Log } \\
\text { (Imports) }\end{array}$ & $\begin{array}{c}\text { Log } \\
\text { (Employment) }\end{array}$ & $\begin{array}{c}\text { Log } \\
\text { (Tourist } \\
\text { Earnings) }\end{array}$ \\
\hline Mean & 14.66 & 10.97 & 10.89 & 11.22 & 15.42 & 7.67 \\
Median & 14.60 & 10.91 & 10.93 & 11.29 & 15.43 & 7.92 \\
Maximum & 16.08 & 15.23 & 14.47 & 15.10 & 15.92 & 13.48 \\
Minimum & 13.39 & 6.86 & 7.39 & 7.49 & 14.95 & 1.66 \\
Standard & 0.81 & 2.73 & 2.50 & 2.63 & 0.32 & 3.57 \\
Deviation & 0.12 & $(0.03)$ & $(0.14)$ & $(0.15)$ & 0.03 & $(0.36)$ \\
Skewness & 1.84 & 1.73 & 1.54 & 1.61 & 1.65 & 1.99 \\
Kurtosis & 0.18 & 0.14 & 0.07 & 0.08 & 0.11 & 0.15 \\
Probability & $\left(\mathrm{I}_{1}\right)$ & $\left(\mathrm{I}_{0}\right)$ & $\left(\mathrm{I}_{1}\right)$ & $\left(\mathrm{I}_{1}\right)$ & $\left(\mathrm{I}_{0}\right)$ & $\left(\mathrm{I}_{1}\right)$ \\
$\begin{array}{l}\text { ADF Unit } \\
\text { Root Test }\end{array}$ & $-5.74 * * *$ & $-3.53^{* *}$ & $-5.43 * * *$ & $-6.15^{* * *}$ & $-4.45 * * *$ & $-4.60^{* * *}$ \\
$\begin{array}{l}\text { No. of } \\
\text { Observations }\end{array}$ & 59 & 59 & 59 & 59 & 59 & 59 \\
\hline
\end{tabular}

Notes:

- $\quad$ Statistical significance at $1 \%, 5 \%$, and $10 \%$ levels are indicated by $* * *, * *$, and $*$ 


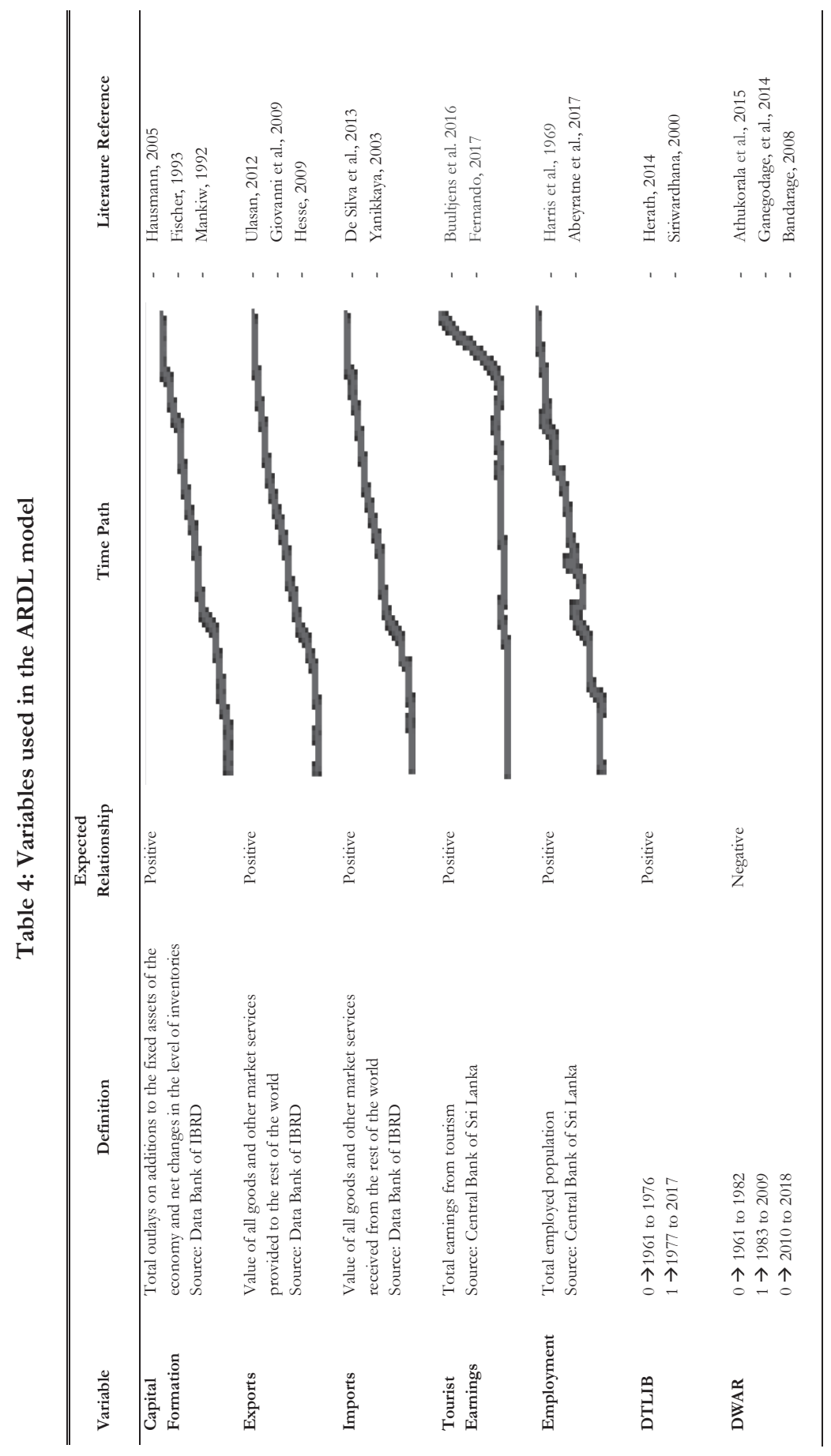


Table 5: Long run results of selected ARDL models

\begin{tabular}{lccc}
\hline \multicolumn{1}{c}{ Model } & $\mathbf{( 8 )}$ & $\mathbf{( 9 )}$ & $\mathbf{( 1 0 )}$ \\
\hline Capital Formation & $0.5242^{* * *}$ & $0.4417^{* * *}$ & $0.3109^{* * *}$ \\
& {$[0.0490]$} & {$[0.1152]$} & {$[0.1148]$} \\
Exports & $0.2494^{* * *}$ & -0.0039 & -0.3022 \\
& {$[0.0970]$} & {$[0.2549]$} & {$[0.2517]$} \\
Imports & $-0.4465^{* * *}$ & -0.0548 & 0.4339 \\
& {$[0.1367]$} & {$[0.3906]$} & {$[0.3928]$} \\
Employment & 0.1548 & 0.1747 & --- \\
Tourist Earnings & {$[0.1457]$} & {$[0.2252]$} & $-0.1052^{* *}$ \\
& -0.0411 & $-0.0843 *$ & {$[0.0522]$} \\
R & {$[0.0265]$} & {$[0.0454]$} & 0.8832 \\
D.W. Stat & 0.9054 & 0.9072 & 2.32 \\
Bound test Statistic & 2.37 & 2.89 & 6.62 \\
\hline
\end{tabular}

Notes:

- $\quad$ Estimated by ARDL, all models satisfy coefficient diagnostic tests (serial correlation, heteroskedasticity and normality), stability diagnostics (recursive estimates, CUSUM test) and the Bounds test show the existence of long run relationship.

- $\quad$ Numbers in parentheses are standard errors

- $\quad$ Statistical significance at $1 \%, 5 \%$, and $10 \%$ levels are indicated by $* * *, * *$, and $*$

- The dependent variable is $\log$ (real GDP), Capital Formation is log of gross capital formation. Exports, Imports and Tourists Earnings represent the log of total export, import and earnings from tourism, respectively. Employment is the total number of people employed in each year.

Source: Author's Calculation

Further, it is essential to mention that the country has a proper labour force database only after 1996. ${ }^{19}$ Employment data used in this analysis is spliced together from several sources, including the annual reports of the Central Bank of Sri Lanka, the Employees' Provident Fund and labour force survey data. The sum of government and private sector employment is used as a proxy to capture the actual employment levels of the country before 1996. However, employment data from 1960 to 1996 presumably have a fundamental limitation of the exclusion of a relatively high self-employment sector, which mainly comprised own-account workers and unpaid family workers.

Although results show that earnings from tourism exert a weak but statistically significant impact on growth in the short run, results containing the long run impact of tourism on growth

\footnotetext{
${ }^{19}$ Labour Force Survey of Department of Census and Statistics, Sri Lanka; sample survey conducted once in two to three years
} 
are unsatisfactory as opposed to Srinivasan et al. (2012) and Jayathilake (2013) suggest. When the effect of war is removed from the regression (Model 9), the negative impact becomes weaker. ${ }^{20}$ Supportively Suresh and Senthilnathan (2014) show that growth and tourism earnings preserve a uni-directional causal relationship, from growth to tourism, not vise versa. The finding is justifiable since tourism has re-flourished after the war, and the current level of development in tourism could have depended on the level of GDP achieved thus far. However, the weaker performance of the sector in the aftermath of the Easter Sunday incident, and during unstable political situations, prove that stability and growth of the industry are highly vulnerable to the external and domestic shocks.

This study finds a significant positive impact from trade liberalisation and real GDP growth of the Sri Lankan economy. Results agree with the findings of Herath (2014) and Athukorala and Jayasooriya (1994). Further, imports negatively and exports positively drive the GDP growth in the long run, whereas both imports and exports show a detrimental impact on growth, in the short run. Findings of Abhayaratne (1996), and Shirazi and Manap (2005) agree with the findings in the short run. The long run negative impact of imports on economic growth could be coming in several ways. Consumer goods imports and import of intermediate goods such as petroleum, industrial materials, etc., hold a larger share of massive import bills, whereas non-productive goods import has increased over time while adding pressure to the current account deficit. Also, the less stable exchange rate has also contributed negatively to the import performance.

The negative impact of civil war on growth is a distinct finding, and other empirical and pragmatic evidence establishes the fact that the war arrested the revival of the economy, which otherwise would have been realised (Bandarage, 2008). For instance, the growth of agriculture, tourism and FDI were severely affected by the war. The error correction term provides a measure for the speed of adjustment to reestablish the dynamic model. The negative and significant results at one per cent level confirm that a long run equilibrium exists, and any deviation from the long run growth due to a shock could adjust at a speed of 48 per cent in the short run (Model 8).

\footnotetext{
${ }^{20}$ In both models 8 and 9 , the short run impact of tourist earnings is positive but statistically not significant.
} 
Table 6: Short run results of the ARDL

\begin{tabular}{ccccc}
\hline \hline Variable & Coefficient & Std. Error & t-Statistic & Prob. \\
\hline DLOG (REAL_GDP (-1)) & 0.196247 & 0.093081 & 2.108354 & 0.0472 \\
D(LCPF) & 0.179399 & 0.017506 & 10.24806 & 0.0000 \\
D(LEX) & -0.023972 & 0.023468 & -1.021489 & 0.3186 \\
D(LIM) & -0.086588 & 0.023500 & -3.684582 & 0.0014 \\
D(LEMP) & -0.041920 & 0.033181 & -1.263358 & 0.2203 \\
D(LTE) & 0.000542 & 0.009837 & 0.055109 & 0.9566 \\
DTLIB & 0.032993 & 0.005610 & 5.880893 & 0.0000 \\
DWAR & -0.007682 & 0.005741 & -1.338015 & 0.1952 \\
Cointegration Eq (-1) & -0.476936 & 0.062013 & -7.690957 & 0.0000 \\
\hline
\end{tabular}

Notes:

- Results of the Model 8 is presented in this table.

- DWAR is the dummy to represent the war period and DTLIB is a dummy to represent trade liberalisation.

Source: Authors Calculations

\subsection{Fixed effects model}

Table 7 summarises the results of the panel data analysis. Notably, the results of the panel data model for the Sri Lankan economy is broadly in line with the results of the ARDL models. Results make it evident that capital accumulation, proxied by gross fixed capital formation, mainly supports the real per capita GDP growth of the region. Results are robust and statistically significantly different from zero at one per cent level in each mix of variables. The time trend shows a highly significant positive impact on per capita GDP growth, implying that there is a significant impact coming from time varying unobservable factors, such as technological progress on real per capita GDP growth of the South Asian economies. Imports show an unexpected adverse effect on real per capita GDP growth, agreeing with the results of the ARDL model. 
Table 7: Results of panel data models for South Asian economies

\begin{tabular}{|c|c|c|c|c|}
\hline Model & (1) & (2) & (4) & (5) \\
\hline $\begin{array}{l}\text { Capital } \\
\text { Formation }\end{array}$ & $\begin{array}{c}0.0412^{* *} \\
(0.0203)\end{array}$ & $\begin{array}{c}0.0521 * * * \\
(0.0181)\end{array}$ & $\begin{array}{c}0.1596^{* * * *} \\
(0.0258)\end{array}$ & $\begin{array}{c}0.1486^{* * *} \\
(0.0282)\end{array}$ \\
\hline Imports & $\begin{array}{l}-0.0023 \\
(0.0181)\end{array}$ & & $\begin{array}{l}-0.0267 \\
(0.2548)\end{array}$ & $\begin{array}{l}-0.0282 \\
(0.0278)\end{array}$ \\
\hline Exports & $\begin{array}{c}0.0134 \\
(0.0154)\end{array}$ & & $\begin{array}{l}0.0301 * \\
(0.0239)\end{array}$ & $\begin{array}{c}0.0285 \\
(0.0262)\end{array}$ \\
\hline FDI & $\begin{array}{c}0.5622 \\
(0.4310)\end{array}$ & $\begin{array}{c}0.4000 \\
(0.3843)\end{array}$ & $\begin{array}{c}0.6607 \\
(0.3553)\end{array}$ & $\begin{array}{l}0.6458^{*} \\
(0.3886)\end{array}$ \\
\hline Trade Openness & & $\begin{array}{l}-0.0177 \\
(0.0172)\end{array}$ & & \\
\hline $\begin{array}{l}\text { Trade } \\
\text { Liberalisation }\end{array}$ & & $\begin{array}{c}0.0131 * * * \\
(0.0034)\end{array}$ & & \\
\hline HH Index & & & $\begin{array}{l}-0.0275 \\
(0.0444)\end{array}$ & $\begin{array}{c}-0.2848^{* *} \\
(0.1082)\end{array}$ \\
\hline HH Index ${ }^{2}$ & & & & $\begin{array}{c}0.4436^{* * *} \\
(0.2214)\end{array}$ \\
\hline Time trend & & & $\begin{array}{c}0.0015^{* * *} \\
(0.0003)\end{array}$ & \\
\hline C & $\begin{array}{c}0.0290 * * * \\
(0.0015)\end{array}$ & $\begin{array}{c}0.0198 * * * \\
(0.0029)\end{array}$ & $\begin{array}{c}-2.9372 * * * \\
(0.7043)\end{array}$ & $\begin{array}{c}0.0617 * * * \\
(0.0094)\end{array}$ \\
\hline Period & $1975-2017$ & $1975-2017$ & $2000-2015$ & 2000-2015 \\
\hline Observations & 210 & 210 & 80 & 80 \\
\hline Model & FE Model & FE Model & FE Model & FE Model \\
\hline
\end{tabular}

Notes:

- Statistical significance at 1\%,5\%, and 10\% levels are indicated by ***, **, and * 
In contrast, exports show a positive relationship with the growth of per capita GDP, which is statistically significant at ten per cent significance level. Literature provides many examples supporting the above result, and Rashid et al. (2012) also confirm the same for India, Sri Lanka and Pakistan. As a robustness check, Model 2 uses trade openness in place of the export and import variables. Results highlight the dominant-negative impact of imports. Further, trade liberalisation shows a significant positive relationship with the growth of the selected South Asian economies. In the third model, the $\mathrm{HH}$ index is used as a proxy for the export concentration, which shows a detrimental relationship with real per capita GDP growth, and also agrees with the findings of Hesse (2009). The outcome is robust when non linearity of the $\mathrm{HH}$-index and the time trend variable are included in the analysis. Notably, the results evident that there is a non linear relationship with export concentration and real per capita GDP growth of the selected countries. The findings of Rajapakshe and Arunatilaka (1997), suggest that the growth of SAARC economies could merely be supported by trading amongst themselves and show that domestic matters need to be resolved to attract FDIs. Supportively, our results show that there is a positive relationship between FDI and growth of the region, as initially expected, although it has low explanatory power. Further, cross-section fixed effects are higher for Sri Lanka, followed by Nepal, indicating a higher sensitivity of these countries to the movements of macroeconomic variables. ${ }^{21}$

\section{Conclusion}

Since independence, Sri Lanka has endeavoured to achieve a high and sustained economic growth through diverse policy options. The growth performance of Sri Lanka has been modest on average, throughout the period under review. Invariably it is vital to pay attention to the inside-the-frontier determinants of growth and identifying the idle avenues to improve. In this context, this paper aims to empirically determine the effects of selected key macroeconomic variables on the growth of the Sri Lankan economy and to study the impact of the regional integration on the growth of the Sri Lankan economy, being a member of SAARC.

This study confirms that among other variables, gross capital formation and exports are the main contributors to the growth of the Sri Lankan economy, whereas imports and employment show detrimental impacts. Based on the results of this study, the author wishes

\begin{tabular}{lc}
\hline 21 & Country \\
Bangaladesh & 0.003432 \\
India & -0.001880 \\
Nepal & 0.010562 \\
Pakistan & -0.025422 \\
Sri Lanka & 0.013308
\end{tabular}


to provide the following policy recommendations. Firstly, the import structure needs to be revisited to understand the necessary reforms while assessing potential improvements. Sri Lanka has many comparative advantages compared to other trading partners, and if effectively utilised the country would reap more benefits. Also, the country should find ways to diversify its export structure, to ensure that exports have higher value addition to the economy, as it would further promote economic growth. Sri Lanka needs proper diversification and promotion policies supporting export oriented industries and import substitution, and it emphasises the need for vertical and horizontal trade diversification (export basket and destinations) by moving away from primary products to high value added products. Also, policy reforms are needed to improve the competitiveness of our products in international markets, and to facilitate the small scale investors to reach global value chains.

Secondly, it is observed that there is no significant impact of employment on GDP growth. Sri Lanka is in a challenging situation in terms of labour productivity, and more specifically, the morale of employees to contribute effectively in their jobs needs to get a boost. Mismatches in supply and demand for labour hinders the expansion of industries, and economic development, whereas scarcity or shortages of labour seem to be structural impediments to growth. Further, labour market reforms are necessary for enhancing the flexibility in the management of labour and for increasing female labour force participation. Furthermore, the country needs to take appropriate policy initiatives to grow the knowledge base of the labour force, encouraging higher education, controlling educated unemployment, providing necessary skills development training for employees and dealing with out-migration of skilled labour. Particularly, Sri Lanka needs to make crucial policy measures to address the mismatch between the skills earned by graduates at the university level and skill demands of the markets to provide a steady and reliable supply to the market while supporting sustainable economic growth.

Thirdly, it should be emphasised that maintaining political and social stability in the country is essential, especially for enhancing the international competitiveness of tourism, as well as to attract foreign investments to the country. Notably, adverse effects on small scale stakeholders, due to skewed distribution of the industry towards larger scalers, should be studied and appropriate policy measures must be taken for the balanced growth of the industry. However, the performance of the tourism industry must be studied comprehensively, including sectoral distributions and the impact of globalisation on the growth of tourism, which are not covered under the purview of the current study.

Fourthly, based on the results of the analyse of South Asian economies, it is interesting to note that Sri Lanka moderately follows the growth pattern of the region, being a small open economy in the region. As the evidence is strong that there is a non linear positive relationship between export concentration and the growth of the selected South Asian economies, the need for having proper policies for export diversification is confirmed. Also, the importance 
of taking necessary efforts further to deepen the trade relationships with the regional economies is emphasised, based on the results of both ARDL and the panel data model, which would otherwise drive the future growth thrust.

Finally, the author highlights the need for a broader long term plan for the sustainable development of each sector, while paying due attention to the interconnectedness of the industries. Many works of literature point out the fact that inconsistent macroeconomic policies hinder the economic growth of Sri Lanka. Thus, the need for immediate structural reforms to support trade and investments utilising the available policy spaces is emphasised as a policy outcome of this study. Further, misallocations in productive resources need to be addressed while minimising uneven resource distribution, combined with stringent regulatory measures for maintaining the quality of production and efficiency in fund allocation considering economic costs and benefits. On the other hand, integrated and long term strategies should be in place for supporting infrastructure developments to facilitate medium to the long run growth momentum of the economy. Also, in impeding an adverse investment climate in war-affected areas, structural reforms are necessary for inclusive growth of the economy, while mobilising labour abundant potential resources effectively. However, the increasing vulnerability of the country due to widening current account deficit, exchange rate volatility and increasing debt levels, disappoint investments, thus growth. The author further highlights the need for second-generation policy reforms in the country, such as doing business ranking and improving institutional quality, knowledge and infrastructure to attain higher regional growth.

The author also wishes to highlight the impact of omitted variable bias and measurement errors on the bias in the regression results. Further, recognising what drives the progressive change of the production structure should be one of the mainstream components of growth studies, as inside-the-frontier development is undoubtedly not enough for high and sustained growth of an economy. Therefore, as an extension of this study, an analysis on technological progress and total factor productivity growth of the economy could be carried out, in order to identify the structural factors that drive the growth thrust of the Sri Lankan economy. Further, with the purpose of overcoming some endogeneity issues inherent to the fixed-effect estimates of the panel data model, this study could be extended with a Dynamic Panel or Generalised Method of Moments (GMM) to analyse the growth of south Asian economies. Although many critics level their allegations against various economic and social factors being root causes of failure for reaching the expected level of growth, the author is of the view that negative contributors to inside-the-frontier growth need to be well identified and thought out, before making recommendations for policy initiatives to stimulate the future thrust of growth of the economy. 


\section{References}

Abhayaratne, A. S. "Foreign trade and economic growth evidence from Sri Lanka, 1960-1992." Applied Economics Letters, 3(9), 1996, pp.567-570.

Abeyratne, Sirimal, et al. "The Sri Lankan Economy: Charting a New Course." 2017.

Abeyratne, Sirimal. "Economic roots of political conflict: The case of Sri Lanka." World Economy, 27.8, 2004, pp.1295-1314.

Acemoglu, D. "Introduction to economic growth." Journal of economic theory, 147(2), 2012, pp. 545-550.

Ahmed, S. and Ghani, E. "Growth and regional integration. South Asia Growth and Regional Integration." Daryaganj, New Delhi, 2007.

Akaike, H. "Likelihood of a model and information criteria." Journal of econometrics, vol. 16, no. 1, 1981, pp. 3-14.

Alfaro, L. \& Chauvin, J. "Foreign Direct Investment, Finance, and Economic Development.” Boston MA 02163, USA, 2016.

Alfaro, L. "Foreign direct investment and growth: Does the sector matter." Harvard Business School, 2003, pp. 1-31.

Ali, M. "A Critical Study of Regionalism in South Asia: Challenges and Perspectives (A Case Study SAARC).” Dialogue, vol. 9, no. 3, 2014, p. 240.

Arunatilake, N. Jayasuriya, S. and Kelegama, S. "The economic cost of the war in Sri Lanka." World Development, vol. 29, no. 9, 2001, pp. 1483-1500.

Athukorala, P.C. and Jayasuriya, S. "Macroeconomic Policies, Crises, and Growth in Sri Lanka 196990.” IBRD, Washington, DC (USA), 1994.

Athukorala, P.C. and Jayasuriya, S. "Victory in war and defeat in peace: politics and economics of post-conflict Sri Lanka.” Asian Economic Papers, 14(3), 2015, pp. 22-54.

Athukorala, P.C. and Jayasuriya, S. "Economic policy shifts in Sri Lanka: the post-conflict development challenge." Asian Economic Papers, 12(2), 2013, pp. 1-28.

Bal, D.P., Dash, D.P. and Subhasish, B. "The effects of capital formation on economic growth in India: Evidence from ARDL-bound testing approach." Global Business Review, 17(6), 2016, pp. 1388-1400. 
Balamurali, N \& Bogahawatte, C. "Foreign direct investment and economic growth in Sri Lanka." Sri Lankan Journal of Agricultural Economics, vol. 6, no. 1, 2011.

Baltagi, B. "Econometric analysis of panel data." John Wiley \& Sons, 2008.

Bandarage, A. "The separatist conflict in Sri Lanka: Terrorism, ethnicity, political economy." Routledge, 2008.

Barrell, R. and Pain, N. "Foreign direct investment, technological change, and economic growth within Europe." The Economic Journal, vol. 107, no. 445, 1997, pp. 1770-1786.

Barro, R.J. "Economic growth in a cross section of countries." The quarterly journal of economics, 106(2), 1991, pp. 407-443.

Barro, R.J. "Determinants of economic growth: a cross-country empirical study." National Bureau of Economic Research, No. w5698, 1996.

Barro, R.J. "Human capital and growth." The American Economic Review, vol. 91, no. 2, 2001, pp. $12-17$.

Bastian, S."The Political Economy of Post War Sr Lanka." International Centre for Ethnic Studies, 2013.

Becker, G.S., Murphy, K.M. and Tamura, R. "Human capital, fertility, and economic growth." Journal of political economy, 98(5, Part 2), 1990, pp. S12-S37.

Borensztein, E., De Gregorio, J. and Lee, J.W. "How does foreign direct investment affect economic growth?.” Journal of international Economics, vol. 45, no. 1, 1998, pp. 115-135.

Brida, J.G., Cortes-Jimenez, I. and Pulina, M. "Has the tourism-led growth hypothesis been validated? A literature review." Current Issues in Tourism, 19(5), 2016, pp. 394-430.

Buultjens, J.W., Ratnayake, I. and Gnanapala, W.A.C. "Post-Conflict tourism development in Sri Lanka: implications for building resilience." Current Issues in Tourism, vol. 19, no. 4, 2016, pp. 355-372.

Carkovic, M.V. and Levine, R. "Does foreign direct investment accelerate economic growth." University of Minnesota, 2002.

Chandralal, K.P.L. "Impacts of tourism and community attitude towards tourism: A case study in Sri Lanka." South Asian Journal of Tourism and Heritage, vol. 3, no. 2, 2010, pp. 41 49. 
De Silva, N., Malaga J.E. and Johnson, J.W., "Trade liberalisation effects on agricultural production growth, The case of Sri Lanka." Southern Agricultural Economics Association, Annual (S AEA) Meeting, Orlando, Florida, 2013, pp. 2-5.

Dickens, W.T. and Lang, K. "An analysis of the nature of unemployment in Sri Lanka.” National Bureau of Economic Research, No. w3777, 1991.

Duma, N. “Sri Lanka's sources of growth.” International Monetary Fund, No. 7-225, 2007.

Dunham, D. and Kelegam, S. "Does leadership matter in the economic reform process? Liberalisation and governance in Sri Lanka, 1989-1993.” World Development, vol. 25, no.2, 1997, pp. 179-190.

Enders, W. “Applied Econometric Time Series, by Walter.” Technometrics, vol. 46, no. 2, 2004, pp. 264.

Engle, R.F. \& Granger, C.W. "Co-integration and error correction: representation, estimation, and testing." Econometrica: Journal of the Econometric Society, 1987, pp. 251-276.

Fernando, S. "Managing the post war tourism development in Sri Lanka." International Journal of Business and Social Science, 7(11), 2016, pp. 90-100.

Fernando, S. "The tourism-led development strategy in Sri Lanka." Journal of Business and Technology, 1(1), 2017, pp. 38-52.

Fischer, S. "The role of macroeconomic factors in growth." Journal of Monetary Economics, vol. 32, no. 3, 1993, pp. 485-512.

Ganegodage, K.R. and Rambaldi, A.N. "Economic consequences of war: Evidence from Sri Lanka." Journal of Asian Economics, vol. 30, 2014, pp. 42-53.

Gelb, A., Knight, J.B. and Sabot, R.H. "Public sector employment, rent seeking and economic growth.” The Economic Journal, 101(408), 1991, pp. 1186-1199.

Giovanni, J.D. and Levchenko, A.A. "Trade openness and volatility." The Review of Economics and Statistics, vol. 91, no. 3, 2009, pp. 558-585.

Greene, W.H. “Econometric analysis.” Pearson Education India, 2003.

Grossman, G.M. and Helpman, E. "Quality ladders in the theory of growth." The review of economic studies, 58(1), 1991, pp. 43-61.

Gounder, R. “Aid-growth nexus: empirical evidence from Fiji." Applied Economics, 33(8), 2001, pp. 1009-1019. 
Gujarati, D.N. "Basic Econometrics $4^{\text {th }}$ Ed. (Tata McGraw- Hill Edition)." p 806, New Delhi: Tata McGraw- Hill Publishing Company Ltd, 2004.

Gunatlilaka, R., Mayer, M. and Vodopivec, M. (eds.) "The challenge of youth employment in Sri Lanka.", World Bank publications, 2010.

Harris, J.R. and Todaro, M.P. "Wages, industrial employment and labour productivity: the Kenyan experience.”, Eastern Africa Economic Review, 1(1), 1969, pp. 29-46.

Jayathilake, P.B. "Tourism and economic growth in Sri Lanka: Evidence from cointegration and causality analysis" International Journal of Business, Economics and Law, 2(2), 2013, pp. 22-27.

Hausmann, R., Pritchett, L. and Rodrik, D. "Growth accelerations", Journal of Economic Growth, vol. 10, no. 4, 2005, pp. 303-329.

Herath, H.M.S.P., Liang, C. and Yongbing, C. "Trade Liberalisation in Sri Lanka: Effects on Exports and Imports." Sri Lankan Journal of Banking and Finance (SLJBF) ,1.01, 2013.

Hesse, Heiko. "Export diversification and economic growth." Breaking into new markets: Emerging lessons for export diversification, 2009, pp. 55-80.

Iqbal, M.J. "SAARC: origin, growth, potential and achievements." Pakistan Journal of History and Culture, vol. 27, no. 2, 2006, pp. 127-140.

Johansen, S. \& Juselius, K. "Maximum likelihood estimation and inference on cointegration with applications to the demand for money", Oxford Bulletin of Economics and statistics, vol. 52, no. 2, 1990, pp. 169-210.

Kaldor, N. "Capital accumulation and economic growth." In The theory of capital, Palgrave Macmillan, London, 1961, pp. 177-222.

Karimi, M.S. and Yusop, Z. "FDI and economic growth in Malaysia." MPRA, No. 14999, 2009.

Lakshman, W.D. (eds) "Income distribution and poverty. Dilemmas of Development", Colombo: Sri Lanka Association of Economists, 1997.

Lanka, D.C.I.S. “Sri Lanka Development Update.” 2019.

Levine, R. and Renelt, D. "A sensitivity analysis of cross-country growth regressions." The American economic review, 1992, pp. 942-963.

Levine, R. and Zervos, S. "Stock markets, banks, and economic growth", American economic review, 1998, pp.537-558. 
Lindgren, Göran. "Measuring the Economic Costs of Internal Armed Conflict-A Review of Empirical Estimates." Universidad de Uppsala, Suecia. Ponencia para la conferencia "Haciendo que funcione la Paz", que tuvo lugar en Helsinki los dias, Vol. 4, 2004.

Lokuhetty, A., Jayawardena, C.C. and Mudadeniya, D. "Developing a shared vision for tourism in post war Sri Lanka." Worldwide Hospitality and Tourism Themes, no. 5(5), 2013, pp. 486-494.

Lucas, Robert. "On the Mechanics of Economic Development," Journal of Monetary Economics 22, No. 1, 1988, pp. 3-42.

Malhotra, A. and DeGraff, D.S. "Entry versus success in the labor force: Young women's employment in Sri Lanka.” World Development 25, no. 3, 1997, pp. 379-394.

Manike, H.R.A. "Inward-Looking Development Strategies and Economic Development in Sri Lanka Since 1948 To 1977.” International Journal of Economics, Commerce and Management, 2018.

Mankiw, N. Gregory, David Romer, and David N. Weil. "A contribution to the empirics of economic growth." The quarterly journal of economics ,107.2, 1992, pp. 407-437.

Mattli, W. "The logic of regional integration: Europe and beyond." Cambridge University Press, 1999.

Pesaran, M.H., Shin, Y. \& Smith, R.J. "Bounds testing approaches to the analysis of level relationships", Journal of Applied Econometrics, vol. 16, no. 3, 2001, pp. 289-326.

Rahman, S.H., Khatri, S. \& Brunner, H.P. "Regional integration and economic development in South Asia." Edward Elgar Publishing, 2012.

Rajapakse, P. and Arunatilake, N. "Would a reduction in trade barriers promote intra-SAARC trade? A Sri Lankan perspective." Journal of Asian Economics, vol. 8, no. 1, 1997, pp. 95-115.

Rashid, F., Ullah, S. and Bedi-uz-Zaman Ullah, S. "Effects of exports instability on economic growth in SAARC region countries", Pakistan Journal of Commerce and Social Sciences (PJCSS), 6(1), 2012, pp. 97-120.

Schiff, M. and Winters, L.A. "Regional integration and development.” The World Bank, 2003.

Schultz, T.W. (1961) "Investment in human capital", The American economic review, pp.1-17.

Shirazi, N.S. and Manap, T.A.A. "Export-led growth hypothesis: Further econometric evidence from South Asia." The Developing Economies, 43(4), 2005, pp. 472-488. 
Shrestha, M.B. and Bhatta, G.R. "Selecting appropriate methodological framework for time series data analysis." The Journal of Finance and Data Science, 4(2), 2018, pp. 71-89.

Siriwardana, M. "Looking beyond SAARC: some trade liberalisation options for Sri Lanka." Asian Studies Review, 25(4), 2001, pp. 453-477.

Solow, R.M. "A contribution to the theory of economic growth." The quarterly journal of economics, 70(1), 1956, pp. 65-94.

Solow, R.M. "Technical progress, capital formation, and economic growth." The American Economic Review, 52(2), 1962, pp. 76-86.

Srinivasan, P., Kumar, P.S., and Ganesh, L. "Tourism and economic growth in Sri Lanka: An ARDL bounds testing approach." Environment and Urbanization Asia, vol. 3, no. 2, 2012, pp. 397-405.

Suresh, J. and Senthilnathan, S. "Relationship between tourism and economic growth in Sri Lanka", 7th chapter of "Economic Issues in Sri Lanka", 2014, pp. 115-132.

Swan, T.W. "Economic growth and capital accumulation." Economic record, 32(2), 1956, pp. 334-361.

Thambiah, S.J. "Sri Lanka: Ethnic fratricide and the dismantling of democracy.” London, 1986.

Ulasan, B. "Openness to international trade and economic growth: a cross-country empirical investigation.” Economics Discussion Papers, No. 2012-25, 2012.

Verma, R. "Savings, investment and growth in India: an application of the ARDL bounds testing approach.” South Asia Economic Journal, 8(1), 2007, pp. 87-98.

Weerakoon, D., Kumar, U. and Dime, R. "Sri Lanka"s Macroeconomic Challenges: A Tale of Two Deficits.”2019.

Wooldridge, J.M. "Introductory econometrics: A modern approach.” Nelson Education, 2008.

Yanikkaya, H. "Trade openness and economic growth: a cross-country empirical investigation", Journal of Development Economics, vol. 72, no. 1, 2003, pp. 57-89.

Zaman, K., Rashid, K., Khan, M.M. and Ahmad, M. "Panel data analysis of growth, inequality and poverty: evidence from SAARC countries." Journal of Yasar University, vol. 21, no. 6, 2011, pp. 3523-3537.

Zhang, K.H. "Does foreign direct investment promote economic growth? Evidence from East Asia and Latin America", Contemporary economic policy, vol. 19, no. 2, 2001, pp. 175-185. 


\section{Appendices}

A.1 Short run (static effect) and long run (dynamic effect) relationships of an ARDL model

$$
Y_{t}=A_{0}+A_{1} Y_{t-1}+B_{0} X_{t}+B_{1} X_{t-1}+U_{t}
$$

Short run effect: $\frac{\partial Y_{t}}{\partial X_{t}}=B_{0}$

Long run Effect:

$$
\begin{aligned}
& \frac{\partial Y_{t}}{\partial X_{t}}=B_{0} \\
& \frac{\partial Y_{t+1}}{\partial X_{t}}=A_{1} \frac{\partial Y_{t}}{\partial X_{t}}+B_{1}=A_{1} B_{0}+B_{1} \\
& \frac{\partial Y_{t+2}}{\partial X_{t}}=A_{1} \frac{\partial Y_{t+1}}{\partial X_{t}}=A_{1}\left(A_{1} B_{0}+B_{1}\right) \\
& \frac{\partial Y_{t+3}}{\partial X_{t}}=A_{1} \frac{\partial Y_{t+2}}{\partial X_{t}}=A_{1}{ }^{2}\left(A_{1} B_{0}+B_{1}\right) \\
& \frac{\partial Y_{t+1+\infty}}{\partial X_{t}}=A_{1} \frac{\partial Y_{t+\infty}}{\partial X_{t}}=A_{1}{ }^{\infty}\left(A_{1} B_{0}+B_{1}\right)
\end{aligned}
$$

Long run slope is the sum of all derivatives.

Slope $\begin{aligned}\left(\mathrm{S}_{1}\right)= & B_{0}+\left[A_{1} B_{0}+B_{1}\right]+\left[A_{1}\left(A_{1} B_{0}+B_{1}\right)\right]+\left[A_{1}{ }^{2}\left(A_{1} B_{0}+B_{1}\right)\right]+ \\ & {\left[A_{1}{ }^{\infty}\left(A_{1} B_{0}+B_{1}\right)\right] }\end{aligned}$

$\mathrm{S}_{1} \times A_{1}=\left\{\left[A_{1} B_{0}+B_{1}\right]+\left[A_{1}\left(A_{1} B_{0}+B_{1}\right)\right]+\left[A_{1}{ }^{2}\left(A_{1} B_{0}+B_{1}\right)\right]+\left[A_{1}{ }^{\infty}\left(A_{1} B_{0}+\right.\right.\right.$ $\left.\left.\left.B_{1}\right)\right]\right\} \times A_{1}$

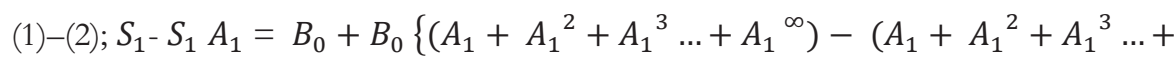

$$
\begin{aligned}
& \left.\left.A_{1}{ }^{\infty}\right)\right\}+B_{1}+B_{1}\left\{\left(A_{1}+A_{1}{ }^{2}+A_{1}{ }^{3} \ldots+A_{1}{ }^{\infty}\right)-\left(A_{1}+A_{1}{ }^{2}+\right.\right. \\
& \left.\left.A_{1}{ }^{3}{ } \ldots+A_{1}{ }^{\infty}\right)\right\}
\end{aligned}
$$

$S_{1}\left(1-A_{1}\right)=B_{0}+B_{1}$ and $S_{1}=\frac{B_{0}+B_{1}}{1-A_{1}}$

Long run effect: $\frac{\partial Y_{T}}{\partial X_{t}}=\frac{B_{0}+B_{1}+B_{2} \ldots \ldots .+B_{q}}{1-A_{1}-A_{2} \ldots \ldots . .-A_{p}}$ 


\section{Error correction Model}

$$
\begin{gathered}
Y_{t}-Y_{t-1}=A_{0}+A_{1} Y_{t-1}-Y_{t-1}+B_{0} X_{t}-B_{0} X_{t-1}+B_{0} X_{t-1}+B_{1} X_{t-1}+U_{t} \\
\Delta Y_{t} \quad=A_{0}-\left(1-A_{1}\right) Y_{t-1}+B_{0} \Delta X_{t}+\left(B_{0}+B_{1}\right) X_{t-1}+U_{t} \\
\Delta Y_{t} \quad=B_{0} \Delta X_{t}-\left(1-A_{1}\right)\left[Y_{t-1}-\frac{A_{0}}{1-A_{1}}-\frac{\left(B_{0}+B_{1}\right)}{\left(1-A_{1}\right)} X_{t-1}\right]+U_{t} \\
\Delta Y_{t} \quad=B_{0} \Delta X_{t}-\pi\left[Y_{t-1}-\alpha-\beta X_{t-1}\right]+U_{t} \\
\Delta Y_{t}=B_{0} \Delta X_{t}-\pi E C T_{t-1}+U_{t}
\end{gathered}
$$

